\title{
Innovative Green Technologies of Intensification for Valorization of Seafood and Their By-Products
}

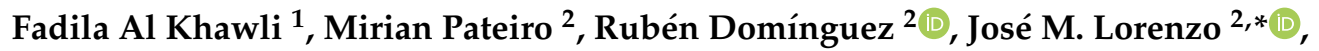 \\ Patricia Gullón ${ }^{2}$, Katerina Kousoulaki ${ }^{3}$, Emilia Ferrer ${ }^{1, * \mathbb{D}}$, Houda Berrada ${ }^{1, * \mathbb{D}}$ and \\ Francisco J. Barba ${ }^{1, *(D)}$
}

1 Department of Preventive Medicine and Public Health, Food Science, Toxicology and Forensic Medicine, Faculty of Pharmacy, Universitat de València, Avda. Vicent Andrés Estellés, s/n 46100 Burjassot, València, Spain; khawli@alumni.uv.es

2 Centro Tecnológico de la Carne de Galicia, Rúa Galicia No 4, Parque Tecnológico de Galicia, San Cibrao das Viñas, 32900 Ourense, Spain; mirianpateiro@ceteca.net (M.P.); rubendominguez@ceteca.net (R.D.); patriciagullon@ceteca.net (P.G.)

3 Department of Nutrition and Feed Technology, Nofima AS, 5141 Bergen, Norway; katerina.kousoulaki@nofima.no

* Correspondence: jmlorenzo@ceteca.net (J.M.L.); emilia.ferrer@uv.es (E.F.); houda.berrada@uv.es (H.B.); francisco.barba@uv.es (F.J.B.); Tel.: +34-988-548-277 (J.M.L.); +34-96-3544-950 (E.F.); +34-96-3544-117 (H.B.); +34-96-3544-972 (F.J.B.); Fax: +34-988-548-276 (J.M.L.); +34-96-3544-954 (E.F. \& H.B. \& F.J.B.)

Received: 21 October 2019; Accepted: 3 December 2019; Published: 6 December 2019

\begin{abstract}
The activities linked to the fishing sector generate substantial quantities of by-products, which are often discarded or used as low-value ingredients in animal feed. However, these marine by-products are a prominent potential good source of bioactive compounds, with important functional properties that can be isolated or up-concentrated, giving them an added value in higher end markets, as for instance nutraceuticals and cosmetics. This valorization of fish by-products has been boosted by the increasing awareness of consumers regarding the relationship between diet and health, demanding new fish products with enhanced nutritional and functional properties. To obtain fish by-product-derived biocompounds with good, functional and acceptable organoleptic properties, the selection of appropriate extraction methods for each bioactive ingredient is of the outmost importance. In this regard, over the last years, innovative alternative technologies of intensification, such as ultrasound-assisted extraction (UAE) and supercritical fluid extraction (SFE), have become an alternative to the conventional methods in the isolation of valuable compounds from fish and shellfish by-products. Innovative green technologies present great advantages to traditional methods, preserving and even enhancing the quality and the extraction efficiency, as well as minimizing functional properties' losses of the bioactive compounds extracted from marine by-products. Besides their biological activities, bioactive compounds obtained by innovative alternative technologies can enhance several technological properties of food matrices, enabling their use as ingredients in novel foods. This review is focusing on analyzing the principles and the use of UAE and SFE as emerging technologies to valorize seafoods and their by-products.
\end{abstract}

Keywords: high-added value compounds; seafood by-products; innovative green technologies; functional foods

\section{Introduction}

Fish is considered to be healthy, and to be among the most nutritious animal-derived foods, due to their content in a high quality of proteins, balanced essential amino acids, high levels of fat-soluble 
vitamins (A and D) and essential macro- and microminerals (iodine, magnesium, phosphorus and selenium) [1].

Moreover, marine fatty fish contain high levels of long chain highly unsaturated $n-3$ fatty acids, which have been associated with reduction of the risk of cardiovascular diseases in humans [2]. Fish nutrient composition, mostly characterized by $15 \%-30 \%$ proteins, $0 \%-25 \%$ lipids and $50 \%-80 \%$ moisture, depends upon fish species, age, gender, health, nutritional status and time of the year. For instance, white fish such as cod and hake are lean species, containing ca. $20 \%$ protein, $80 \%$ water and rather low lipids levels $(0.5 \%-3 \%)$, whereas fatty fish, such as mackerel and salmon, contain $20 \%$ protein, $10 \%-18 \%$ lipids, and correspondingly lower water content $(62 \%-70 \%)$ [3].

In 2016, fish production worldwide amounted to ca. 171 million tons, 91 million tons deriving from inland and marine fisheries, and 80 million tons from aquaculture, with China being the largest producer [4]. In Europe, Norway and Spain are topping the list of the largest producing countries for capture fisheries (2.03 and 0.91 million of tons, respectively). As a consequence of the activities related to the different fishing sectors, a great amount of fish by-products, not utilized for direct human consumption, are generated every year, and they can represent anything betwen $30 \%$ and $85 \%$ of the weight of the different catches [5]. The food fish to by-product ratio varies by fishing zone, season, fish size and species [6]. Besides bycatch, fisheries and aquaculture by-products include fish fins, backbones, gills, heads, belly flaps, liver, roe, skin, viscera, among others [7]. Indicatively, heads represent $9 \%-12 \%$, viscera $12 \%-18 \%$, skin $1 \%-3 \%$, bones $9 \%-15 \%$ and scales ca. $5 \%$ of whole fish weight [8].

Fish by-products can entail significant environmental and food-technical challenges due to their high microbial and endogenous enzyme load, rendering them susceptible to rapid degradation if not processed properly or stored in appropriate conditions $[9,10]$. Fish by-products can be classified into two types: One that includes easily degradable products with high enzyme content, such as viscera and blood, and a second one that includes the more stable products (bones, heads and skin) [5]. Timely collection and the treatment of fish by-products is a crucial step in maintaining their quality to be used as raw materials for obtaining high added-value products [5] Given that fish production, landing and processing locations are spread geographically, it appears that the best management option that would allow the conversion of fish residues into products of greater value is that of processing locally immediately after production [11]. To achieve this, significant investments, for instance, on board fishing vessels, would be required, not easy to justify unless already developed markets for the new end-products are present. By refining seafood by-products, high-added value components for the production of nutraceuticals and bioactive ingredients can be obtained. Processing fish proteins can generate bioactive peptides, amino acids and other bioactive nitrogenous compounds [12], whereas fish oil by-products generated from a fish oil refinery can be utilized as raw materials for the production of the essential long chain, polyunsaturated fatty acids concentrates, eicosapentaenoic acid (EPA) and docosahexaenoic acid (DHA), to be used in food supplements [13].

To succeed in utilizing marine resources in a responsible and good way, it is indispensable to establish efficient and safe methods for the extraction of the target nutrients and bioactives. Downstream processing in the biomass refinery includes, among others, conventional techniques, already widely used for the separation, selective upconcentration and extraction of target compounds, such as in fish meal and fish oil [14] or EPA- and DHA-rich oil production [15]. These methods are efficient, and their main drawback is related to the high energy consumption and potential thermal degradation of target compounds, due to the high processing temperatures. Other extraction methods involving the use of organic solvents would entail risks for human health and the environment, and may also lead to perishable compound degradation, should prolonged extraction periods be involved [16].

In recent years, the concept of green technology, assuming the use of more environmentally-friendly techniques for ingredient processing, has emerged [17]. Innovative alternative extraction technologies, such as supercritical fluid extraction (SFE), ultrasound-assisted extraction (UAE), pulsed electric fields 
(PEF) or microwave-assisted extraction (MAE), have been identified as green extraction techniques for the separation of high-added value compounds [18,19].

These alternative technologies have several advantages, including rapid extraction, low solvent consumption rates, use of alternative environmentally-friendly solvents, superior compound recovery rates and higher selectivity.

This review intends to summarize the potential applications of UAE and SFE, as green technologies, for the extraction of a wide range of bioactive compounds from fish side stream biomasses, and thus achieve the valorization of seafood and their by-products. Moreover, this review also aims to provide detailed information on the potential benefits of applying these innovative technologies for a by-product refinery in both academy and the industry.

\section{Valorization of Fish By-Products}

There are multiple possibilities in valorizing marine by-products through processing, as for instance creating more valuable ingredients or extracting specific high-value compounds. Following the European Union (EU) Directive 2008/98/CE, a standard prioritization scheme can be established, visualized by a pyramid in which the obtained product value, as well as the necessary quality of the raw material used, decrease from top to bottom [20]. The main aspect in the model for marine biomass valorization is linked to the application of good practices, and therefore the prevention or reduction of wastes. Millions of tons of captured fish are returned to the sea for failing to comply with regulations regarding legal size, no control over catch rates, or low quality. This forced the European Union to establish a new fisheries' policy that involves actions paving the way towards zero-discards [21]. To meet the goals set by the new policy, novel management measures must be established enabling the valorization of fish side stream biomasses. Maintaining marine catch discards and by-products in the food chain can be practiced either through the commercialization of low-value fractions, or through the production of ingredients and high-value biomolecules that can be used in the pharmaceutical and nutraceutical industry [22-25], fulfilling the principles of a sustainable circular economy (green approach). This complementary approach allows an efficient use of fish by-products, transforming them into ingredients that can be incorporated into feed, food or other high-value products (Figure 1). Use of fish by-products in animal feeds (flours and oils), is the most common option practiced today $[26,27]$. Finally, waste from the above processes may also have the potential to be used in biofuel production or be exploited in other agronomic and industrial applications, as for instance fertilizers $[28,29]$.

The known healthy compounds and properties associated with fish are also present in their by-products. A great number of bioactive compounds can be obtained from fish by-products [11,13,30-32]: collagen [33], chitin [34], enzymes [35], gelatin [36], glycosaminoglycans [37,38], polyunsaturated fatty acids (PUFA) [39], minerals [40,41], protein and peptides [10,42,43] and vitamins. It should be noted that the long-chain omega-3 fatty acids (LC-PUFAs), eicosapentaenoic acid (EPA) and docosahexaenoic acid (DHA), are among the most successful compounds extracted from fish by-products, achieving a high value in the market due to their beneficial health effects [11]. Marine by-product-derived compounds are known to induce positive effects on human health associated with their, e.g., anticancer, antidepressant, anti-diabetic, antihyperglycemic, antihypertensive, anti-inflammatory, antimicrobial, antioxidant, antiproliferative, anti-rheumatoid and immunomodulatory properties [42-44]. Besides their biological activities exploited by pharmaceutical, nutraceutical and cosmeceutical industries [45], marine by-product ingredients can also provide desirable technological properties when included in food products, acting for instance as emulsifying and foaming agents, and facilitating fat binding, solubility and water holding capacity [46,47]. Recent data show that it is possible to modify fish burger technical properties, in terms of hardness, cohesiveness, juiciness and adhesiveness, by the addition of low amounts fish by-product protein powder or fish hydrolysates [48]. 


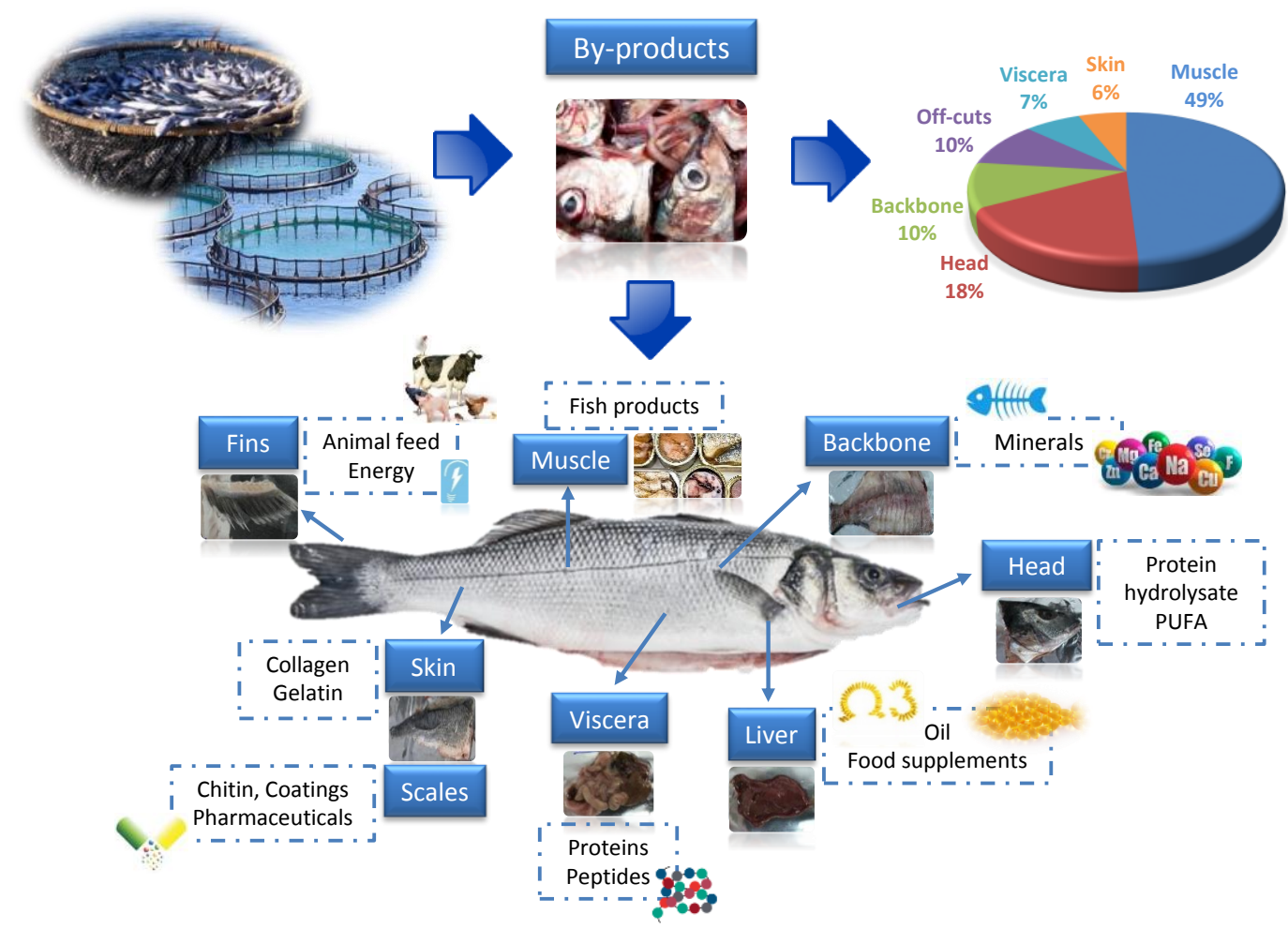

Figure 1. Fish processing by-product generation and end use opportunities.

\section{Emerging Technologies for the Extraction of Bioactive Compounds from Fishery By-Products}

Several techniques can be used to extract bioactive compounds, thus valorizing fish by-products. Among the conventional methods that are used for the extraction of fishery by-products. it is possible to highlight enzymatic hydrolysis for the solubilization and upconcentration of fish proteins, as reviewed by Aspevik et al. (2017), and among others, lipid extracton by Soxhlet, steam distillation and the use of solvents. Some traditional extraction methods, besides being characterized by low extraction yields, long extraction time, high solvent and high energy consumption and potential health hazards [16], involve extraction conditions ( $\mathrm{pH}$, temperature, extraction time, solvent type, concentration, etc.) that can alter the functional properties of potentially valuable compounds. Therefore, there is a need to explore alternative processing technologies that can better preserve target bioactive components $[49,50]$, operating at lower temperatures and avoiding as much as possible the use of solvents. The shortcomings of these conventional methods have stimulated the interest in emerging green technologies. Several techniques, such as PEF, UAE, MAE, SFE and high pressure can be used to extract bioactive compounds, thus valorizing fish by-products [51,52]. Among these innovative, alternative techniques are ultrasounds-assisted (UAE) and supercritical fluid extraction (SFE), which are the object of the present review.

\subsection{Ultrasound-assisted Extraction (UAE)}

\subsubsection{Fundamentals}

The use of ultrasound has increased, and has been applied over the last years with the scope to minimize processing, maximize the quality and ensure the safety of food products. This technique is applied in improving the technological properties of food, such as emulsification ability, solubility and texture, as well as on applications such as preservation, homogenization, viscosity alteration, extraction, drying, crystallization and antifoaming actions and enzymatic activation and inactivation [53]. Nowadays, improvements in ultrasound technology grant the opportunity to extract bioactive compounds with economic advantages, and this is referred to as innovative UAE [53]. 
Ultrasound works in frequencies above human hearing levels, ranging from $20 \mathrm{kHz}$ to $10 \mathrm{MHz}$ [53], and is classified by the amount of energy generated as sound power $(\mathrm{W})$, sound intensity $\left(\mathrm{W} / \mathrm{m}^{2}\right)$, or sound power density $\left(\mathrm{W} / \mathrm{m}^{3}\right)$. The use of ultrasounds can be divided into two types: high intensity and low intensity. Low-intensity ultrasounds with high frequency (100 kHz to $1 \mathrm{MHz}$ ), and low-power $<1 \mathrm{~W} / \mathrm{cm}^{2}$ are used as non-destructive methods for evaluating the physical and chemical properties in food products [54], whereas high-intensity ultrasounds have low frequency $(20 \mathrm{kHz}-100 \mathrm{kHz})$ and high power $>1 \mathrm{~W} / \mathrm{cm}^{2}$, and are used to speed up and improve the efficiency of sample preparation, as they can alter the physical or chemical properties of food [54].

UAE is generally recognized as an effective tool used in extraction methods, significantly minimizing the time required to increase both the productivity and the quality of the product. Numerous studies have critically assessed a variety of UAE applications in the industrial extraction of bioactive compounds [53] and found that this extraction technique enhances the yield of extraction, improving simultaneously their functional properties [55]. UAE efficiency is driven by the creation of acoustic cavitation and mechanical impact in the material matrix (Figure 2). Acoustic cavitation when used in plant materials can disrupt cell walls facilitating the solvent penetration into the sample matrix. Ultrasound mechanical impact increases the surface area of contact between the solvent and the extractable compounds, and hence offers greater penetration of solvents into the sample matrix, releasing in this way the bioactive compounds $[53,56]$. The UAE requires less extraction time and reduced solvent consumption. It can be performed at low temperatures, which can decrease the damages caused by temperature, and reduce the loss of bioactive substances [53]. In contrast, a denaturation of the protein/enzyme can occur when UAE is applied for a long period of time, since it results in high pressures, shear strength and increased temperatures into the medium.

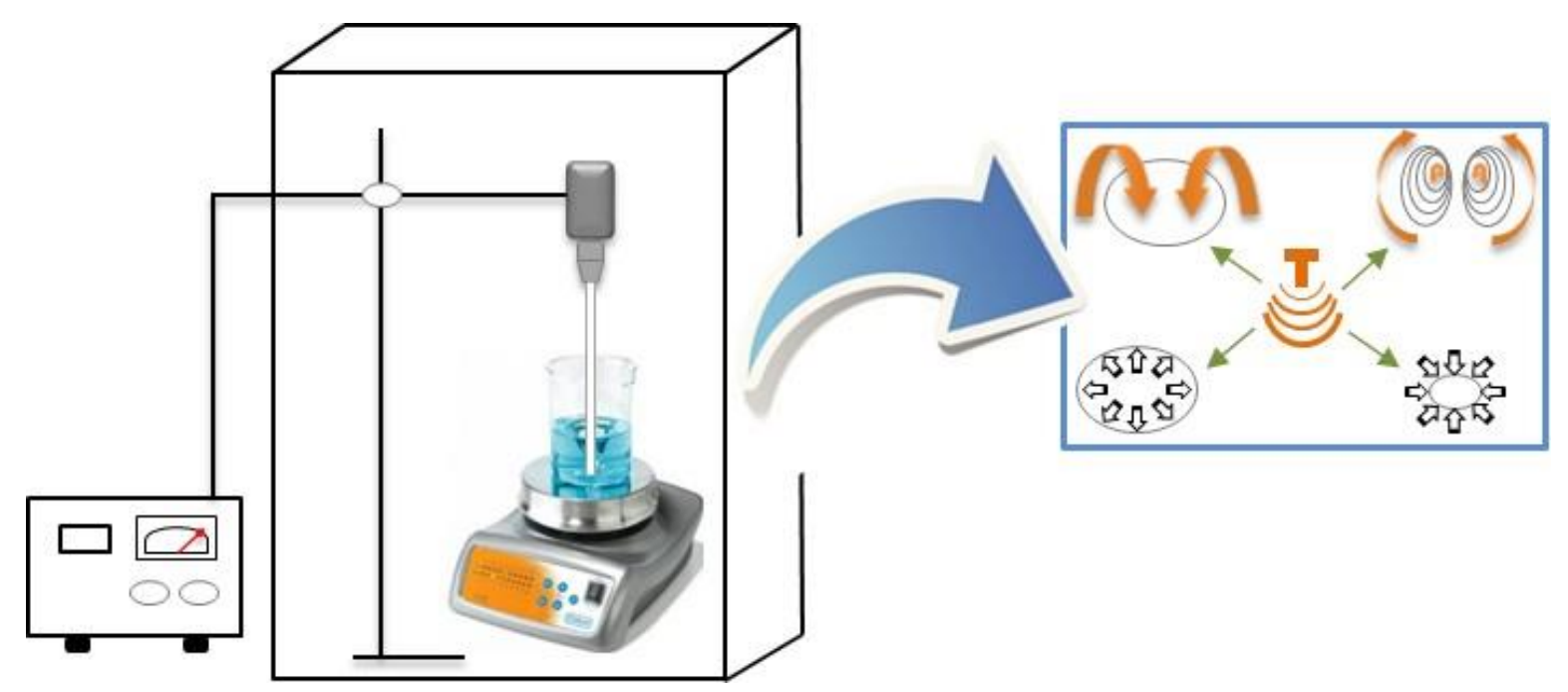

Figure 2. Schematic representation of the ultrasound-assisted extraction (UAE) process and the bubble cavitation phenomenon involved in this extraction technique.

\subsubsection{Use of UAE in Fish Industry}

The utilization of ultrasound technology in the food industry is not new. Recently, UAE became recognized as an efficient, rapid, clean, reproducible and alternative non-thermal extraction technique as compared to conventional extraction methods [53]. Table 1 lists the advantages and drawbacks of the employment of UAE in marine products and discards. The application of UAE results in both the disruption of the material cell structures and an increase in the accessibility of the solvent to the internal particle structure, which enhances the intra-particle diffusivity. Hence, with significant improvements in both the extraction yield and time used, improved efficiency could be achieved when the substrate particle size is reduced [57]. 
Table 1. Advantages and disadvantages of the application of ultrasound-assisted (UAE) extraction in fish and fish by-products for the extraction of bioactive compounds.

\begin{tabular}{|c|c|c|c|c|}
\hline $\begin{array}{l}\text { Extraction } \\
\text { Technique }\end{array}$ & Advantages & Drawbacks & $\begin{array}{l}\text { Extraction } \\
\text { Conditions }\end{array}$ & Solvents \\
\hline \multirow[t]{3}{*}{ UAE } & $\begin{array}{l}\text { Reduction of energy, } \\
\text { time and solvent } \\
\text { consumption }\end{array}$ & $\begin{array}{l}\text { Can induce lipid oxidation: } \\
\text { increasing temperature by } \\
\text { cavitation; formation of free } \\
\text { radicals by sonolysis; } \\
\text { mechanical forces generated } \\
\text { by shockwaves and } \\
\text { microstreaming. }\end{array}$ & \multirow{3}{*}{$\begin{array}{c}25 \mathrm{kHz} \\
200-2450 \mathrm{~W} \\
30-60 \mathrm{~min}\end{array}$} & \multirow{3}{*}{$\begin{array}{c}\text { Ethanol, } \\
\text { cyclohexane, other } \\
\text { organic solvents }\end{array}$} \\
\hline & $\begin{array}{l}\text { Safe; does not produce } \\
\text { toxic compounds }\end{array}$ & High power consumption & & \\
\hline & $\begin{array}{l}\text { Higher penetration of } \\
\text { solvent into cellular } \\
\text { material and enhanced } \\
\text { release in medium }\end{array}$ & Difficult to scale up & & \\
\hline
\end{tabular}

In the last decades, researchers have reported that the optimization of several parameters, as for instance ultrasound frequency, propagation cycle (continuous or discontinuous), nominal power of the device, amplitude, type and the geometry of the system (e.g., length and diameter of the probe), improve the efficiency of UAE towards the extraction of target compounds [58]. Currently, UAE is widely used for the recovery of several valuable compounds from seafood by-products (Table 2) [54].

For instance, several studies reveal that UAE can be used successfully for collagen extraction from fish by-products (skin and scales), reducing processing time and increasing yield [59,60]. In the processing skin of Japanese sea bass (Lateolabrax japonicus) for the extraction of collagen using UAE, it was shown that the extraction yield differed according to the amount of acid added, the treatment time and the amplitude of the ultrasonic waves [60]. More in detail, when the treatment time was increased for a long period $(24 \mathrm{~h})$, unknown components were obtained, most probably deriving from a breakdown of collagen, and conducting further optimization trials determined the most effective conditions for the extraction of pure collagen using USE (80\% amplitude with $0.1 \mathrm{M}$ acetic acid for $3 \mathrm{~h}$ of treatment).

Another important peptide for its emulsifying, foaming and gelling properties, is gelatin [61]. Gelatine is a polypeptide, which results from the denaturation of insoluble collagen, shown to have valuable functional properties, such as emulsifying, foaming, gelling, fat binding and water holding capacity [62]. Although the most widely used gelatins are of mammalian origin, the appearance of bovine spongiform encephalopathy (BSE, or mad cow) disease and religious restrictions regarding the consumption of porcine and bovine products, places marine collagen in a favourable position, rendering it as the most important alternative source. Several studies report the potential of using fish by-products, especially skins and bones, as novel sources of marine gelatin [32]. Limiting factors for the large-scale development of the fish gelatin industry are its inferior rheological properties, the lack of sufficient available raw materials and the variable quality of marine gelatin. In addition, other intrinsic quality factors related to odor, color, bloom strength and the viscosity of fish gelatin also limit the use of this gelatin [62].

In a study using the scales of bighead carp (Hypophthalmichthys nobilis), UAE $\left(200 \mathrm{w}, 60{ }^{\circ} \mathrm{C}\right.$, different extraction times from $1 \mathrm{~h}$ to $5 \mathrm{~h}$ ) allowed an increase in extraction yields (30.94-46.67\%) and the quality of the gelatin obtained as compared to using a water bath [63]. The authors reported that the extraction yields obtained with an ultrasound bath at $60^{\circ} \mathrm{C}(46.67 \%)$ was also higher than those obtained with the water bath (36.39\%) [63]. Furthermore, fish scales gelatins extracted with UAE are shown to have higher gelling and melting points, gel strength, apparent viscosity and emulsifying properties, compared to those obtained with a water bath extraction [59]. In another study, gelatin extracted by UAE was shown to have higher thermal stability compared with gelatin extracted by a conventional extraction. 
However, the application of a higher ultrasound intensity (over $200 \mathrm{~W}$ ) and a more extended extraction time (above $5 \mathrm{~h}$ ) can lead to the decrease in gel strength and melting points of gelatin, which may cause protein degradation due to acoustic cavitation [63].

Table 2. Bioactive compounds obtained from fish and shellfish by-products by UAE.

\begin{tabular}{|c|c|c|c|c|c|}
\hline By-Product & Source & $\begin{array}{l}\text { Bioactive } \\
\text { Compound } \\
\text { and Product }\end{array}$ & Extraction Conditions & Main Effects & Ref. \\
\hline Head & Labeo rohita & Oil & $\begin{array}{c}\text { UAE: } 20 \mathrm{kHz}, 40 \% \\
\text { amplitude, for } 5,10 \text { and } \\
15 \mathrm{~min} . \\
\text { Enzymatic hydrolysis: } \\
\text { Protamex ratio of } 1: 100 \\
(w / w), 2 \mathrm{~h}, 150 \mathrm{rpm}, 55^{\circ} \mathrm{C} .\end{array}$ & $\begin{array}{l}\text { Pretreatments with UAE } \\
\text { improved the extraction yield } \\
\text { of oil, showing higher oil } \\
\text { recoveries ( } 67.48 \% \text { vs. } 58.74 \% \\
\text { for SFE and untreated } \\
\text { samples, respectively). }\end{array}$ & [64] \\
\hline \multirow[t]{2}{*}{ Scales } & $\begin{array}{c}\text { Bighead carp } \\
\text { (Hypophthalmichthys } \\
\text { nobilis) }\end{array}$ & Gelatin & $\begin{array}{l}\text { Temperature: } 60,70 \text { and } \\
80^{\circ} \mathrm{C} \\
\text { Extraction time: } 1 \mathrm{~h}\end{array}$ & $\begin{array}{c}\text { Improved technological } \\
\text { properties: highest storage } \\
\text { modulus }(5000 \mathrm{~Pa}) \text {, gelation } \\
\text { point }\left(22.94{ }^{\circ} \mathrm{C}\right) \text {, and melting } \\
\text { point }\left(29.54^{\circ} \mathrm{C}\right) .\end{array}$ & [59] \\
\hline & $\begin{array}{c}\text { Bighead carp } \\
\text { (Hypophthalmichthys } \\
\text { nobilis) }\end{array}$ & Gelatin & $\begin{array}{c}\text { Temperature: } 60^{\circ} \mathrm{C} \\
\text { Extraction time: } 1,3 \text { and } \\
5 \mathrm{~h}\end{array}$ & $\begin{array}{l}\text { Extraction yield: } 46.67 \% \text { for } \\
\text { ultrasound bath versus } 36.39 \% \\
\text { for water bath. }\end{array}$ & [63] \\
\hline Shells & $\begin{array}{l}\text { Prawns } \\
\text { (Macrobrachium } \\
\text { rosenbergii) }\end{array}$ & Chitin & $\begin{array}{l}\text { Extraction time: } 0,1 \text {, and } \\
44 \mathrm{~h} \\
0.25 \mathrm{M} \mathrm{NaOH} \text { at solid to } \\
\text { liquid ratio of } 1: 40(w / v) \\
\text { Power: } 41 \mathrm{~W} / \mathrm{cm} .\end{array}$ & $\begin{array}{c}\text { Decrease of the crystallinity } \\
\text { indices and extraction yield of } \\
\text { chitin as the time of sonication } \\
\text { increased. }\end{array}$ & [65] \\
\hline Skin & $\begin{array}{l}\text { Japanese sea bass } \\
\text { (Lateolabrax } \\
\text { japonicus) }\end{array}$ & Collagen & $\begin{array}{c}\text { UAE: } 20 \mathrm{kHz}, 80 \% \\
\text { amplitude, } 0.1 \mathrm{M} \text { acetic } \\
\text { acid, } 3 \mathrm{~h} .\end{array}$ & $\begin{array}{l}\text { UAE did not alter the major } \\
\text { components of collagen }(\alpha 1 \text {, } \\
\alpha 2 \text { and } \beta \text { chains }) .\end{array}$ & [60] \\
\hline Whole fish & Mackerel & Proteins & $\begin{array}{c}\text { ISP: Isoelectric } \\
\text { solubilization } \\
\text { precipitation. } \\
\text { UAE: } 40 \mathrm{kHz}, 60 \% \\
\text { amplitude, } 0.1 \mathrm{M} \mathrm{NaOH}, \\
10 \mathrm{~min} .\end{array}$ & $\begin{array}{l}\text { Significant increase of protein } \\
\text { recovery, recovering more } \\
\text { than } 95 \% \text { of total protein from } \\
\text { mackerel by-products. }\end{array}$ & [66] \\
\hline
\end{tabular}

Chitin, a polysaccharide present in the exoskeleton of crustaceans (shells) and the endoskeleton (pen) of cephalopods [67], is another compound that can be extracted with UAE. The influence of sonication time $(0,1$ and $4 \mathrm{~h}$ ) on yield, purity and crystallinity was evaluated during the extraction of chitin from North Atlantic shrimp (NAS) shells (Pandalus borealis). The investigation showed that the crystallinity indices and the extraction yield of chitin decreased as the sonication time increased (from $8.28 \%$ to $5.02 \%$ after $4 \mathrm{~h}$ of sonication treatments). Meanwhile, the extraction yield increased from $7.45 \%$ to $44.01 \%$ after $4 \mathrm{~h}$ of sonication treatment (Table 2) [65].

The combination of UAE with other technologies has also been studied in processing different fish by-products in order to improve the extraction efficiency and the quality of extracted bioactive compounds. In summary, pre-treatment with emerging technologies has the potential to increase the quality of the extracted compounds and thus their beneficial properties, as by using these techniques it is possible to nearly maintain their composition and structure intact.

Combining different novel technologies, such as UAE with enzymes, has also been demonstrated to improve extraction yields, facilitating an increase in collisions between enzyme and substrate [68]. Ultrasound-assisted enzymatic extraction is considered as a promising method for the improvement of the extraction yield of oil from marine matrices. Bruno et al. [64] evaluated the effects of pretreatments with UAE before enzymatic extraction on the extraction yield, fatty acid profile, oxidative stability and rheological properties of oil extracted from Labeo rohita heads (Table 2). The results showed higher oil recoveries, higher PUFA contents and higher oxidative stability in the samples subjected to a pretreatment with UAE before enzymatic hydrolysis. Besides, lower apparent viscosity and sensitivity to temperature changes were observed in the oil extracted using both UAE and enzymes as compared to enzymes alone [64]. 
In addition, Álvarez et al. [66] investigated the influence of UAE in the protein extraction yield from mackerel by-products by isoelectric solubilization precipitation (ISP). ISP is an emerging technology that uses $\mathrm{pH}$ changes to promote protein extraction. Several parameters influence the yield of extraction using this technology, such as the raw material quality as well as the extraction conditions ( $\mathrm{pH}$, temperature and extraction time). It was reported that by applying $60 \%$ of amplitude for $10 \mathrm{~min}$ in $0.1 \mathrm{M} \mathrm{NaOH}$ solution it was possible to recover $\approx 94 \%$ of total raw material protein in a single extraction step. It was also shown that lower amplitudes $(20 \%)$ of ultrasonic bath increases the yield of the extraction when compared to traditional ISP. Furthermore, applying UAE to alkaline extraction allowed the recovery of more than $95 \%$ of total protein from mackerel by-products [66]. Therefore, the use of UAE in combination with ISP for protein extraction from fish by-products can give higher yields, using lower extraction times and less solvent [69].

\subsection{Supercritical Fluid Extraction (SFE)}

\subsubsection{Fundamentals}

SFE is an alternative extraction method that has attracted a growing attention in food industries in the last decade. It is considered a green technology due to the utilization of non-toxic organic solvents, which results in more sustainable processing and reduced energy use and environmental pollution (Table 1) [70]. In SFE, solvents are used at above or near their critical temperature and pressure to separate solutes from a liquid or solid matrix under pressurized conditions. Under these conditions the solvents have intermediary properties between gases and liquids, which facilitates the extraction of the target compounds (Figure 3). Carbone dioxide $\left(\mathrm{CO}_{2}\right)$ is the most widely used SFE solvent in food applications, since it is generally recognized as safe (GRAS) [71]. $\mathrm{CO}_{2}$ is not only cheap and easily available at high purity, but also lacks toxicity and flammability. It has a moderate critical temperature and pressure $\left(31.1^{\circ} \mathrm{C}\right.$ and $\left.7.4 \mathrm{MPa}\right)$, and can be readily removed by a simple pressure reduction [72]. Furthermore, its higher diffusion coefficient and lower viscosity allow the rapid penetration through the pores of heterogeneous matrices, like gas, helping to dissolve the solute like a liquid. The efficiency of the SFE process is mostly affected by pressure, extraction temperature, extraction time, $\mathrm{CO}_{2}$ density, $\mathrm{CO}_{2}$ flow rate and co-solvent concentration [73]. The SFE selectivity is achieved by adjusting temperature and pressure, resulting in alterations of the density. This selectivity can also be adjusted by the use of a co-solvent, either to increase or decrease the polarity of $\mathrm{CO}_{2}$. The most frequently used co-solvent is ethanol, because it meets the green technology requirements.

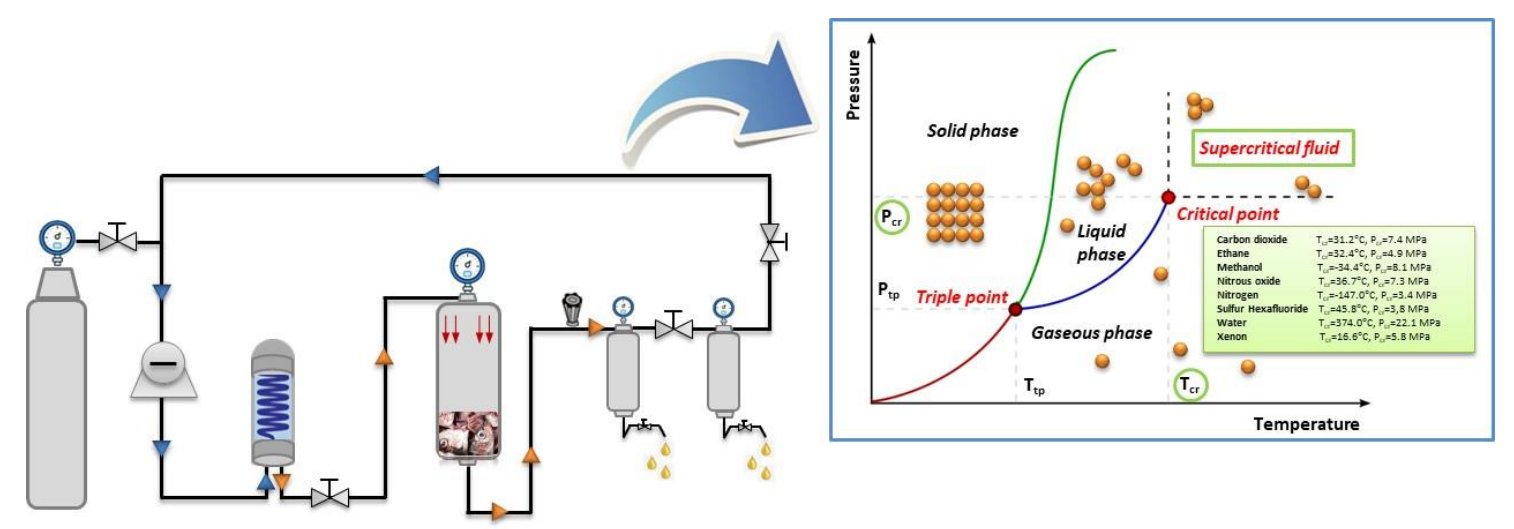

Figure 3. Schematic representation of supercritical fluid extraction (SFE) and the mechanism involved in this extraction technique. 


\subsubsection{Application of SFE in By-Products from Fish Industry}

SFE has been used widely in several areas of food technology for food safety, food drying and sterilization, and food oil removal applications. This extraction technique is already being applied in the extraction of valuable compounds from natural materials, such as plant and marine sources. Several natural compounds, such as vitamins, flavors, natural pigments and essential oils, are extracted with SFE, thus avoiding the use of organic solvents and high temperatures [74]. So far, most of the studies that have evaluated the potential of SFE to extract biomolecules from fish by-products have focused upon lipid-soluble and antioxidant compounds [73,75]. Table 3 collects the advantages and drawbacks of the employment of SFE in processing marine products and discards.

Table 3. Advantages and disadvantages of the application of supercritical fluid (SFE) extraction in fish and fish by-products for the extraction of bioactive compounds.

\begin{tabular}{|c|c|c|c|c|}
\hline $\begin{array}{l}\text { Extraction } \\
\text { Technique }\end{array}$ & Advantages & Drawbacks & $\begin{array}{l}\text { Extraction } \\
\text { Conditions }\end{array}$ & Solvents \\
\hline \multirow{4}{*}{ SFE } & $\begin{array}{c}\text { Green extraction } \\
\text { Technique. No need for } \\
\text { organic solvent, and therefore } \\
\text { the extract is very pure. Lipids } \\
\text { can be used immediately }\end{array}$ & $\begin{array}{c}\text { Very expensive and } \\
\text { complex equipment } \\
\text { operating at elevated } \\
\text { pressures }\end{array}$ & \multirow{4}{*}{$\begin{array}{l}25-40 \mathrm{MPa} \\
40-80{ }^{\circ} \mathrm{C} \\
\mathrm{CO}_{2} \text { flow }> \\
2 \mathrm{~mL} / \mathrm{min} \\
45 \mathrm{~min}-6 \mathrm{~h}\end{array}$} & \multirow{4}{*}{$\begin{array}{l}\text { Co-solvent } \\
\text { Ethanol }\end{array}$} \\
\hline & $\begin{array}{l}\text { Maintain the quality of the } \\
\text { final product. Low operating } \\
\text { temperatures }\left(40-80^{\circ} \mathrm{C}\right)\end{array}$ & $\begin{array}{c}\text { No polar substances are } \\
\text { extracted }\end{array}$ & & \\
\hline & $\begin{array}{c}\text { Free of heavy metals and } \\
\text { inorganic salts }\end{array}$ & $\begin{array}{l}\text { High power } \\
\text { consumption }\end{array}$ & & \\
\hline & $\begin{array}{c}\text { Very effective because of its } \\
\text { low viscosity and high } \\
\text { diffusivity. Fast and high yield }\end{array}$ & & & \\
\hline
\end{tabular}

Nowadays, the large demand on fish oil by consumers linked to the large amount of fish by-products generated every year that are discarded has increased the interest regarding the extraction of edible fish oil from fish by-products (Table 4) using SFE. During SFE, the extraction parameters used (extraction time, flow-rate of $\mathrm{CO}_{2}$, pressure and temperature) play a key role on the extraction yield and the lipid composition of the functional products obtained. SFE has been applied to extract an oil fraction from fish meal. Fish meal is one of the primary products obtained from fish processing [76]. Its composition stands out for its higher protein content and balanced amino acid profile, characterized by good digestibility. Fish meals can be used to obtain fish protein concentrates intended for human consumption, as well as low-fat protein hydrolysates, thus achieving consumer demands for healthier fish products [77].

SFE allowed us to reduce the fat content of the produced fish meal without affecting protein quality. Extraction conditions of pressure (10-40 MPa), temperature $\left(25-80{ }^{\circ} \mathrm{C}\right)$, and $\mathrm{CO}_{2}$ flow-rates of $9.5 \mathrm{~g} / \mathrm{min}$ resulted in a product with a $90 \%$ reduction of fat and a lighter color, as with this method pigments such as astaxanthin were also extracted. 
Table 4. Bioactive compounds obtained from fish and fish by-products by SFE.

\begin{tabular}{|c|c|c|c|c|c|}
\hline By-Product & Source & $\begin{array}{l}\text { Bioactive } \\
\text { Compound } \\
\text { and Product }\end{array}$ & SC- $\mathrm{CO}_{2}$ Conditions & Outcomes & Ref. \\
\hline $\begin{array}{c}\text { Canned } \\
\text { by-product }\end{array}$ & Tuna & $\begin{array}{c}\text { Oils } \\
\text { (volatiles) }\end{array}$ & $\begin{array}{l}\text { Temperature } \geq 40{ }^{\circ} \mathrm{C} \\
\text { Pressure } \geq 25 \mathrm{MPa} \\
\mathrm{CO}_{2} \text { flow } \geq 10 \mathrm{~kg} / \mathrm{h} \\
\text { Extraction time: } 3 \mathrm{~h}\end{array}$ & $\begin{array}{c}\text { Extracted oils showed } \\
\text { better conditions, quality } \\
\text { (type of compounds and } \\
\text { indicators of lipid } \\
\text { oxidation) and yield. }\end{array}$ & [78] \\
\hline $\begin{array}{l}\text { Caviar, fillet } \\
\text { and viscera }\end{array}$ & $\begin{array}{l}\text { Carp } \\
\text { (Cyprinus } \\
\text { carpio L.) }\end{array}$ & $\begin{array}{l}\text { Oil (MUFA } \\
\text { and PUFA) }\end{array}$ & $\begin{array}{c}\text { Temperature: } 40,50 \text { and } 60^{\circ} \mathrm{C} \\
\text { Pressure: } 200,300,350 \text { and } 400 \text { bar } \\
\mathrm{CO}_{2} \text { flow: } 0.194 \mathrm{~kg} / \mathrm{h} \\
\text { Extraction time: } 180 \mathrm{~min}\end{array}$ & $\begin{array}{l}\text { Omega-enriched fish oils } \\
\text { (DHA and EPA). High } \\
\text { yields, above } 50 \mathrm{~g} / 100 \mathrm{~g} \text { in } \\
\text { viscera, which are similar to } \\
\text { those obtained with } \\
\text { petroleum ether. }\end{array}$ & [79] \\
\hline Fish meal & n.a. ${ }^{1}$ & $\begin{array}{l}\text { Oil (MUFA } \\
\text { and PUFA) }\end{array}$ & $\begin{array}{c}\text { Temperature: } 25-80^{\circ} \mathrm{C} \\
\text { Pressure: } 10-40 \mathrm{MPa} \\
\mathrm{CO}_{2} \text { flow with ethanol: } 9.5 \mathrm{~g} / \mathrm{min}\end{array}$ & $\begin{array}{l}\text { High reductions of fat } \\
(90 \%) \text {. Extract with a lighter } \\
\text { colour due to astaxanthin } \\
\text { extraction. }\end{array}$ & [77] \\
\hline \multirow[t]{2}{*}{ Head } & \multirow[t]{2}{*}{$\begin{array}{l}\text { Thunnus } \\
\text { tonggol }\end{array}$} & $\begin{array}{l}\text { Fatty acid } \\
\text { (omega } 3 \\
\text { and omega } \\
6 \text { ) }\end{array}$ & $\begin{array}{c}\text { Temperature: } 65^{\circ} \mathrm{C} \\
\text { Pressure: } 40 \mathrm{MPa} \\
\mathrm{CO}_{2} \text { flow with ethanol: } 3 \mathrm{~mL} / \mathrm{min} \\
\text { Extraction time: } 2 \mathrm{~h}\end{array}$ & $\begin{array}{l}\mathrm{SC}-\mathrm{CO}_{2} \text { (co-solvent) is a } \\
\text { good technique to extract } \\
\text { omega } 3 / 6 \text { after } \\
\text { fractionations of oil. }\end{array}$ & [80] \\
\hline & & PUFA & $\begin{array}{c}\text { Temperature: } 65^{\circ} \mathrm{C} \\
\text { Pressure: } 40 \mathrm{MPa} \\
\mathrm{CO}_{2} \text { flow with ethanol: } 2.4 \mathrm{~mL} / \mathrm{min} \\
\text { Ethanol flow: } 0.6 \mathrm{~mL} / \mathrm{min} \\
\text { Extraction time: } 120 \mathrm{~min}\end{array}$ & $\begin{array}{l}\text { Good quality of extracted } \\
\text { PUFA-rich fraction, even } 60 \\
\text { days after storage. }\end{array}$ & [81] \\
\hline $\begin{array}{l}\text { Heads and } \\
\text { tails }\end{array}$ & Sardine & $\begin{array}{l}\text { DHA and } \\
\text { EPA }\end{array}$ & $\begin{array}{l}\text { Temperature: } 75^{\circ} \mathrm{C} \\
\text { Pressure: } 300 \mathrm{bar} \\
\mathrm{CO}_{2} \text { flow: } 2.5 \mathrm{~mL} / \mathrm{min} \\
\text { Extraction time: } 45 \mathrm{~min}\end{array}$ & $\begin{array}{l}\text { Increase of the extraction } \\
\text { yields: DHA (59\%), EPA } \\
(28 \%) .\end{array}$ & [44] \\
\hline Liver & Tuna & Fatty acids & $\begin{array}{c}\text { Step of freeze-drying }(12 \mathrm{~h}) \\
\text { Temperature: } 40^{\circ} \mathrm{C} \\
\text { Pressure: } 35 \mathrm{MPa} \\
\text { Continuous } \mathrm{CO}_{2} \text { flow: } 3 \mathrm{~mL} / \mathrm{min}\left(\text { at } 20^{\circ} \mathrm{C}\right) \\
\text { Extraction time: } 4 \mathrm{~h}\end{array}$ & $\begin{array}{l}\text { High quality and excellent } \\
\text { yield obtained } 98.45 \% .\end{array}$ & [82] \\
\hline Muscle & Mackerel & Vitamins & $\begin{array}{l}\text { Temperature: } 45^{\circ} \mathrm{C} \\
\text { Pressure: } 15-25 \mathrm{MPa} \\
\mathrm{CO}_{2} \text { flow: } 27 \mathrm{~g} / \mathrm{min} \\
\text { Extraction time: } 2 \mathrm{~h}\end{array}$ & $\begin{array}{l}\text { High extraction of vitamins } \\
\text { A, D2, D3 and } \alpha \text {-tocopherol }\end{array}$ & [83] \\
\hline $\begin{array}{l}\text { Muscle, bone } \\
\text { and skin }\end{array}$ & Salmon & Oil (PUFA) & $\begin{array}{l}\text { Temperature: } 45^{\circ} \mathrm{C} \\
\text { Pressure: } 250 \mathrm{bar} \\
\mathrm{CO} 2 \text { Flow: } 27 \mathrm{~g} / \mathrm{min} \\
\text { Extraction time: } 3 \mathrm{~h}\end{array}$ & $\begin{array}{c}\text { Premium quality oil of } \\
\text { physical, biochemical and } \\
\text { biological properties. Yield } \\
76.12 \%-86.99 \% .\end{array}$ & [84] \\
\hline Muscle & Mackerel & $\begin{array}{l}\text { Oil (EPA and } \\
\text { DHA) }\end{array}$ & $\begin{array}{l}\text { Temperature: } 45^{\circ} \mathrm{C} \\
\text { Pressure: } 15-25 \mathrm{MPa} \\
\mathrm{CO}_{2} \text { flow: } 27 \mathrm{~g} / \mathrm{min} \\
\text { Extraction time: } 2 \mathrm{~h}\end{array}$ & $\begin{array}{l}\text { The extracted oil presented } \\
\text { significant contents of } \\
\text { PUFAs (EPA, DHA). Higher } \\
\text { stability compared with } \\
\text { n-hexane extracted oil. }\end{array}$ & [83] \\
\hline \multirow{3}{*}{ Off-cuts } & $\begin{array}{l}\text { Hake } \\
\text { (Merluccius } \\
\text { capensis- } \\
\text { Merluccius } \\
\text { paradoxus) }\end{array}$ & \multirow{4}{*}{$\begin{array}{l}\text { Oil (omega-3 } \\
\text { fatty acids) }\end{array}$} & \multirow{4}{*}{$\begin{array}{l}\text { Temperature: } 313 \mathrm{~K} \\
\text { Pressure: } 25 \mathrm{MPa} \\
\mathrm{CO}_{2} \text { flow: } 880 \mathrm{~kg} / \mathrm{m}^{3}\end{array}$} & \multirow{4}{*}{$\begin{array}{l}\text { PUFA extraction. } \\
\text { Reduction of fish oil } \\
\text { oxidation. Reduction of } \\
\text { certain impurities. } \\
\text { Co-extraction of some } \\
\text { endogenous volatile } \\
\text { compounds. }\end{array}$} & \multirow{4}{*}{ [85] } \\
\hline & $\begin{array}{l}\text { Orange } \\
\text { roughy } \\
\text { (Hoplostethus } \\
\text { atlanticus) }\end{array}$ & & & & \\
\hline & $\begin{array}{c}\text { Salmon } \\
\text { (Salmo salar) }\end{array}$ & & & & \\
\hline Liver & $\begin{array}{c}\text { Jumbo squid } \\
\text { (Dosidicus } \\
\text { gigas) }\end{array}$ & & & & \\
\hline
\end{tabular}


Table 4. Cont.

\begin{tabular}{|c|c|c|c|c|c|c|}
\hline By-Product & Source & $\begin{array}{c}\text { Bioactive } \\
\text { Compound } \\
\text { and Product }\end{array}$ & \multicolumn{2}{|c|}{ SC- $\mathrm{CO}_{2}$ Conditions } & \multirow[b]{2}{*}{$\begin{array}{l}\text { Yield very close to those } \\
\text { obtained with the Soxhlet } \\
\text { technique. }\end{array}$} & \multirow{2}{*}{$\begin{array}{l}\text { Ref. } \\
{[86]}\end{array}$} \\
\hline \multirow{4}{*}{ Skin } & \multirow{4}{*}{$\begin{array}{l}\text { Mackerel } \\
\text { (Rastrelliger } \\
\text { kanagurta) }\end{array}$} & \multirow{4}{*}{ Oil (PUFA) } & $\begin{array}{l}\text { Temperature: } \\
45-75^{\circ} \mathrm{C} \\
\text { Pressure: } \\
20-35 \mathrm{MPa}\end{array}$ & $\begin{array}{l}\text { Continuous: Pressurized (5 } \\
\mathrm{min}, \mathrm{CO}_{2} \text { flow } 2 \mathrm{~mL} / \mathrm{min}\end{array}$ & & \\
\hline & & & & $\begin{array}{c}\text { Co-solvent technique: } \mathrm{CO}_{2} \\
\text { and ethanol ( } 80 \%-20 \% \text { at } 2 \\
\mathrm{~mL} / \mathrm{min}) \text { for } 6 \mathrm{~h}\end{array}$ & $\begin{array}{l}\text { PUFA constituents of } \\
\text { co-solvent, soaking and } \\
\text { pressure swing techniques } \\
\text { were similar to the Soxhlet } \\
\text { method. }\end{array}$ & \\
\hline & & & & $\begin{array}{l}\text { Soaking: Samples soaked } \\
\text { with pure } \mathrm{CO} 2 \text { for } 10 \mathrm{~h} \text { then } \\
\text { extracted for } 6 \mathrm{~h}\end{array}$ & \multirow{2}{*}{$\begin{array}{l}\text { The largest recoveries of } \\
\text { PUFA, especially the } \omega-3 \\
\text { family, were achieved from } \\
\text { the soaking and pressure } \\
\text { swing techniques at } 35 \mathrm{MPa} \\
\text { and } 75^{\circ} \mathrm{C} \text {. }\end{array}$} & \\
\hline & & & & $\begin{array}{l}\text { Pressure swing: Samples } \\
\text { pressurized }\left(\mathrm{CO}_{2}\right)(2 \mathrm{~h} \text {, } \\
\text { extracted } 3 \mathrm{~h}\end{array}$ & & \\
\hline \multirow{4}{*}{ Viscera } & \multirow{3}{*}{$\begin{array}{l}\text { Squid } \\
\text { (Todarodes } \\
\text { pacificus) }\end{array}$} & Enzymes & \multicolumn{2}{|c|}{$\begin{array}{l}\text { Temperature: } 35-45^{\circ} \mathrm{C} \\
\text { Pressure: } 15-25 \mathrm{MPa} \\
\mathrm{CO}_{2} \text { flow: } 22 \mathrm{~g} / \mathrm{min} \\
\text { Extraction time: } 2.5 \mathrm{~h}\end{array}$} & $\begin{array}{l}\text { Thermal stability of } \\
\text { enzymes was slightly } \\
\text { higher than } \\
n \text {-hexane-treated squid } \\
\text { viscera. Denaturation of } \\
\text { proteins did not occur. }\end{array}$ & [87] \\
\hline & & Amino acids & $\begin{array}{c}\text { SFE: } \\
\text { Temperature: } \\
35-45^{\circ} \mathrm{C} \\
\text { Pressure: } \\
15-25 \mathrm{MPa} \\
\mathrm{CO}_{2} \text { flow: } 22 \\
\text { g/min } \\
\text { Extraction } \\
\text { time: } 2.5 \mathrm{~h}\end{array}$ & $\begin{array}{l}\text { SWH: } \\
\text { Temperature: } 180-280{ }^{\circ} \mathrm{C} \\
\text { Pressure: } 0.101-6.41 \mathrm{MPa} \\
\text { Extraction time: } 5 \mathrm{~min}\end{array}$ & $\begin{array}{l}\text { Positive effects of the use of } \\
\text { SFE as a pretreatment } \\
\text { method. Amino acids were } \\
1.5 \text { times higher than those } \\
\text { obtained in non-deoiled } \\
\text { samples. }\end{array}$ & [88] \\
\hline & & Lecithin & $\begin{array}{r}\text { Tem } \\
\text { Pre } \\
\text { C } \\
\text { Ext }\end{array}$ & $\begin{array}{l}\text { serature: } 35-45^{\circ} \mathrm{C} \\
\text { sure: } 15-25 \mathrm{MPa} \\
\text { flow: } 22 \mathrm{~g} / \mathrm{min} \\
\text { action time: } 2.5 \mathrm{~h}\end{array}$ & $\begin{array}{l}\text { Extraction yield was higher } \\
\text { at the highest temperature } \\
\text { and pressure }(0.34 \mathrm{~g} / \mathrm{g} \text { squid } \\
\text { viscera at } 45^{\circ} \mathrm{C} \text { and } 25 \\
\mathrm{MPa}) \text {. Lecithin that was } \\
\text { isolated had in its } \\
\text { composition some } \\
\text { polyunsaturated fatty acids } \\
\text { (EPA and DHA) with a high } \\
\text { oxidative stability. }\end{array}$ & [89] \\
\hline & $\begin{array}{l}\text { Common } \\
\text { carp } \\
\text { (Cyprinus } \\
\text { carpio L.) }\end{array}$ & PUFA & $\begin{array}{r}\text { Temper } \\
\text { Pressure: } \\
\mathrm{CO}_{2} \text { mass flor } \\
\text { Extraction ti }\end{array}$ & $\begin{array}{l}\text { ture: } 40,50 \text { and } 60^{\circ} \mathrm{C} \\
00,300,350 \text { and } 400 \mathrm{bar} \\
: 0.194,0.277 \text { and } 0.354 \mathrm{~kg} / \mathrm{h} \\
\text { ne: } 30,60,120 \text { and } 180 \mathrm{~min}\end{array}$ & $\begin{array}{l}\text { Adequate for the isolation } \\
\text { of bioactive components. } \\
\text { Positive impact on the total } \\
\text { yield and extraction time. }\end{array}$ & [90] \\
\hline
\end{tabular}

Moreover, SFE-extracted oils have also been shown to have higher radical scavenging activity and longer oxidative stability [84]. Using a gas saturated solution process, employing similar extraction conditions as that of SFE, in mackerel muscle, resulted in a more stable and less oxidized oil. However, the yields were low, obtaining oil concentrations of $4.00 \mathrm{~g} / 20 \mathrm{~g}$ of mackerel muscle [83].

Longtail tuna (Thunnus tonggol) heads have also been used to obtain PUFA using SFE [80,81]. Tuna oil, besides omega-3 PUFA, also contains substantial levels of saturated fatty acids (SFA) and undesirable impurities which were extracted by simultaneous fractionation using SFE with ethanol as a co-solvent. In this process, fish oil was extracted and simultaneously collected into six fractions based on molecular weight. The short chain SFA fraction was extracted early, while the latter fractions were dominated by long-chain fatty acids, especially monounsaturated fatty acids (MUFA) and PUFA, particularly rich in DHA among other omega-3 and omega- 6 fatty acids, resulting in a refined product with added value for health. The conditions that yielded optimal results in terms of obtaining a PUFA-rich fraction with a high quality and storage stability were $65^{\circ} \mathrm{C}, 40 \mathrm{MPa}$, with a $\mathrm{CO}_{2}$ flow of $3.0 \mathrm{~mL} / \mathrm{min}$ during $120 \mathrm{~min}$. The results of this study demonstrate that, in applying SFE, the utilization of ethanol as the co-solvent allows us to achieve an upconcentration of PUFA (omega-3 and omega-6) in an effective way, and that using SFE for the extraction of fish oil from fish by-products can play 
an important role in obtaining economic and nutritional benefits, reducing environmental risks [84] (Table 4).

Sahena et al. compared different techniques for oil extraction from Indian mackerel (Rastrelliger kanagurta) skin [86]. Oil from this by-product fraction was extracted by SFE at different pressures (20-35 MPa) and temperatures $\left(45-75^{\circ} \mathrm{C}\right)$, and was compared to Soxhlet extraction $[70,86]$. The authors observed that their oil extraction yield increased with pressure and temperature, being $53.2 \%$ for SFE co-solvent, $52.8 \%$ for soaking pressure and $24.7 \%$ for the continuous technique at $35 \mathrm{MPa}$ and $75{ }^{\circ} \mathrm{C}$. The Soxhlet method achieved the highest extraction yield (53.6\%) compared to that obtained with SFE. Other studies have demonstrated that the pressure swing and soaking techniques are among the most effective ones in extracting oil from fish skin $[70,86]$.

Létisse et al. [44] also evaluated the influence of SFE conditions (pressure, temperature and $\mathrm{CO}_{2}$ rate) on the upconcentration of EPA and DHA in oil from sardine heads and tails. The obtained results confirmed that conditions of $30 \mathrm{MPa}, 75^{\circ} \mathrm{C}, 2.5 \mathrm{~mL} \mathrm{CO} / / \mathrm{min}$ and $45 \mathrm{~min}$ of extraction time allowed the obtaining of yields of $10.36 \%$, and contents of EPA and DHA of $10.95 \%$ and $13.01 \%$, respectively. Rubio-Rodríguez et al. [91] found that the application of lower pressure and temperature (25 MPa, $\left.40{ }^{\circ} \mathrm{C}\right)$, higher $\mathrm{CO}_{2}$ flow $\left(10 \mathrm{~kg} \mathrm{CO}_{2} / \mathrm{h}\right)$ and an upflow direction through the offcuts from two hake species (Merluccius capensis-Merluccius paradoxus) during $3 \mathrm{~h}$ resulted in extracting more than $96 \%$ of the total oil contained in the raw material. High contents of EPA and DHA (about $6 \%$ and $14 \%$, respectively, of the total fatty acids) were obtained in the extracted oil [91]. Furthermore, the application of the aforementioned conditions of temperature and pressure on the off-cuts of orange roughy (Hoplostethus atlanticus) and Atlantic salmon (Salmo salar), as well as on liver from jumbo squid (Dosidicus gigas) resulted in fish oils with reduced PUFA oxidation and less impurities [85]. The application of SFE in tuna livers also allowed to result in oil both rich in n-3 PUFA and vitamins [82].

Fish by-products, such as caviar and viscera, are also an important source of bioactive compounds, especially of monounsaturated (MUFA) and polyunsaturated (PUFA) fatty acids [79]. In the case of viscera, the application of conditions of $400 \mathrm{bar}, 60^{\circ} \mathrm{C}$ and a $\mathrm{CO}_{2}$ flow rate of $0.194 \mathrm{~kg} / \mathrm{h}$ resulted in high yields (above $50 \mathrm{~g} / 100 \mathrm{~g}$ ), which are similar to those obtained with petroleum ether, and the production of omega-enriched fish oils (DHA and EPA). Lisichkov et al. [90] studied the influence of operating parameters (pressure: 200, 300, 350 and 400 bar; temperatures: 40,50 and $60{ }^{\circ} \mathrm{C} ; \mathrm{CO}_{2}$ flow rate: $0.194,0.277$ and $0.354 \mathrm{~kg} / \mathrm{h}$; and extraction time: $30,60,120$ and $180 \mathrm{~min}$ ) on the SFE extraction of PUFA from the viscera of common carp. For this purpose, authors used the 3D response surface methodology (RSM) and found that an equilibrium state was achieved after $180 \mathrm{~min}$, where the curve of the extraction yield and the extraction time reached a plateau.

The higher extraction yield was achieved at $180 \mathrm{~min}$ of extraction time, $60^{\circ} \mathrm{C}$ of temperature, 400 bar of pressure and with a $0.354 \mathrm{~kg} / \mathrm{h} \mathrm{CO}_{2}$ flow rate. A positive impact of the increase of pressure and $\mathrm{CO}_{2}$ flow rate was observed on the extraction time and the total extraction yield, whereas the operating temperature had a complex influence, depending on the values of the operating pressure at isobaric conditions (Table 4) [90].

The yield and quality of oil extraction using different conventional versus emerging technologies were also evaluated by Fang et al. [82], who concluded that the best results were obtained using SFE and SC-dimethyl ether (SDEE), as these methods prevented the oxidation of lipids and reduced the damage of PUFA and vitamins, as compared with conventional methods (wet reduction and enzymatic extraction). Moreover, only a minor difference between the resulting material levels in volatile compounds and vitamins was observed in both SFE and SDEE, which was related to the used solvents' solubility [82]. The disadvantages of SFE are related to high energy consumptions due to the application of high pressures and the need for material preparation by freeze-drying [82]. The limitation of SDEE is its lower critical point density and the related environment hazards [92]. Likewise, Taati et al. [78] found that SFE gives high extraction yields preventing oil oxidation, especially in oils with a high level of triacylglycerol (TAG) and PUFA, and attributed this result to the vacuum conditions and absence of free atmospheric oxygen during processing. 
Finally, following extraction, the residues of fish by-products can also be used as a source of other valuable ingredients, such as amino acids, facilitated by the defattening amounts of the raw material which allows the extraction of other biomolecules [88]. Accordingly, Uddin et al. [88] evaluated the combined effect between SFE and sub-critical water hydrolysis (SWH) in order to obtain valuable materials from squid viscera. SWH is a technique considered as a non-conventional extraction method (green technology) that uses water in a sub-critical state as the solvent (from $100{ }^{\circ} \mathrm{C}$ to $374^{\circ} \mathrm{C}$ at $0.10 \mathrm{MPa}$ and $22 \mathrm{MPa}$, respectively). This enables the extraction of bioactive compounds of an ionic, polar and non-polar nature. This method has been used in several studies for the extraction of peptides and amino acids from animal by-products by hydrolyzing and breaking down the protein [93]. The results obtained in deoiled squid viscera confirmed that the use of SFE before SWH had positive effects on the recovery of amino acids, since the contents obtained in pretreated samples were 1.5 times higher than those obtained from raw squid viscera ( $51 \%$ vs. $76 \%$, respectively).

The viscera of squid (Todarodes pacificus) was also processed to obtain other bioactive compounds such as enzymes and lecithin $[87,89]$. In the first case, $n$-hexane treatment of squid viscera resulted in the highest extraction yield; however, the thermal stability of digestive enzymes (protease, lipase and amylase) were slightly greater in SFE-treated samples [87]. High oxidative stability was also found in squid viscera lecithin subjected to a defattening step using SFE, despite its significant content in LC-PUFAs (EPA and DHA) [89].

\subsubsection{Application of SFE in by-Products from Processing Shellfish}

Shellfish are marine organisms rich in several bioactive components with potential health benefits, which makes them interesting as functional food ingredients [12]. SFE has also been used to extract PUFAs from shrimp by-products (Table 5). Northern shrimp (Pandalus borealis Kreyer) processing by-products, such as heads, shell and tail could be used as a natural source for the development of beneficial health products (omega-3 PUFA) [94]. Depending on the extraction conditions used, different extraction yields and qualities can be obtained. The use of low pressure conditions (15 MPa and $50{ }^{\circ} \mathrm{C}$ ) with flow rates of 3-5 L/min during 90 min showed high selectivity for DHA and EPA, while moderate pressures ( $35 \mathrm{MPa}$ and $40^{\circ} \mathrm{C}$ ) showed increase extraction efficiency but lower yields than those obtained with organic solvents (137 mg oil/g vs. $206 \mathrm{mg}$ oil/100 g and $178 \mathrm{mg}$ oil/g, for SFE, acetone and $n$-hexane, respectively). In contrast, the obtained extract by SFE contained higher total free fatty acids $(795 \mathrm{mg} / \mathrm{g})$, and similar levels of EPA $(7.8 \%)$ and DHA $(8.0 \%)$ to conventional solvent extraction (Soxhlet using acetone and $n$-hexane as solvents), but with lower extraction times (90 min vs. $8 \mathrm{~h}$, for SFE and Soxhlet extraction, respectively).

Table 5. Bioactive compounds obtained from shellfish by-products by supercritical fluid extraction (SFE).

\begin{tabular}{|c|c|c|c|c|c|}
\hline By-Product & Source & $\begin{array}{l}\text { Bioactive } \\
\text { Compound }\end{array}$ & SC- $\mathrm{CO}_{2}$ Conditions & Outcomes & Ref. \\
\hline \multirow{2}{*}{$\begin{array}{l}\text { Head, shells } \\
\text { and tails }\end{array}$} & \multirow{2}{*}{$\begin{array}{c}\text { Brazilian } \\
\text { redspotted } \\
\text { shrimp } \\
\text { (Farfantepenaeus } \\
\text { paulensis) }\end{array}$} & \multirow{2}{*}{$\begin{array}{l}\text { Lipids and } \\
\text { carotenoids }\end{array}$} & $\begin{array}{c}\text { Temperature: } 50^{\circ} \mathrm{C} \\
\text { Pressure: } 30 \mathrm{MPa} \\
\mathrm{CO}_{2} \text { flow: } 4.2 \times 10^{-5} \mathrm{~kg} / \mathrm{s} \\
\text { Extraction time: } 20 \mathrm{~min} \\
\text { Solvent for compounds recovery: } \\
n \text {-hexane }\end{array}$ & $\begin{array}{l}\text { Increase extraction yield: } \\
\text { Astaxanthin }(36 \%)\end{array}$ & \multirow{2}{*}{ [95] } \\
\hline & & & $\begin{array}{c}\text { Temperature: } 50^{\circ} \mathrm{C} \\
\text { Pressure: } 30 \mathrm{MPa} \\
\mathrm{CO}_{2} \text { flow with ethanol: } 8.3 \times 10^{-5} \\
\mathrm{~kg} / \mathrm{s} \\
\text { Ethanol flow: } 4.4 \times 10^{-6} \mathrm{~kg} / \mathrm{s} \\
\text { Extraction time: } 200 \mathrm{~min} \\
\text { Solvent for compounds recovery: } \\
n \text {-hexane }\end{array}$ & $\begin{array}{l}\text { Increase extraction yield: } \\
\text { Astaxanthin }(57.9 \%)\end{array}$ & \\
\hline
\end{tabular}


Table 5. Cont.

\begin{tabular}{|c|c|c|c|c|c|}
\hline By-Product & Source & $\begin{array}{l}\text { Bioactive } \\
\text { Compound }\end{array}$ & SC- $\mathrm{CO}_{2}$ Conditions & Outcomes & Ref. \\
\hline & & & $\begin{array}{c}\text { Temperature: } 43^{\circ} \mathrm{C} \\
\text { Pressure: } 370 \mathrm{bar} \\
\mathrm{CO}_{2} \text { flow: } 1.5 \mathrm{~L} / \mathrm{min} \\
\text { Extraction time: } 200 \mathrm{~min} \\
\text { Solvent for compounds recovery: } \\
n \text {-hexane }\end{array}$ & $\begin{array}{l}\text { Increase extraction yield: } \\
\text { Astaxanthin }(39 \%)\end{array}$ & [96] \\
\hline & $\begin{array}{l}\text { Northern } \\
\text { shrimp } \\
\text { (Pandalus } \\
\text { borealis Kreyer) }\end{array}$ & PUFA & $\begin{array}{l}\text { Temperature: } 40^{\circ} \mathrm{C} \\
\text { Pressure: } 35 \mathrm{MPa} \\
\mathrm{CO}_{2} \text { flow: } 3-5 \mathrm{~L} / \mathrm{min} \\
\text { Extraction time: } 90 \mathrm{~min}\end{array}$ & $\begin{array}{l}\text { Lower yields }(137 \mathrm{mg} \text { oil } / \mathrm{g}) \\
\text { than those obtained in } \\
\text { organic solvent extraction. } \\
\text { Higher contents of total fatty } \\
\text { acid content }(795 \mathrm{mg} / \mathrm{g}) \\
\text { DHA }(8 \%), \text { EPA }(7.8 \%) .\end{array}$ & [94] \\
\hline Liver & $\begin{array}{l}\text { Rock lobsters } \\
\text { (Jasus edwardsii) }\end{array}$ & $\begin{array}{l}\text { PUFA and } \\
\text { vitamins }\end{array}$ & $\begin{array}{c}\text { Temperature: } 50^{\circ} \mathrm{C} \\
\text { Pressure: } 35 \mathrm{MPa} \\
\text { Continuous } \mathrm{CO}_{2} \text { flow: } 0.434 \mathrm{~kg} / \mathrm{h} \\
\text { Extraction time: } 4 \mathrm{~h}\end{array}$ & $\begin{array}{l}\text { Enrichment in PUFAs (DHA, } \\
\text { EPA) vs. Soxhlet extraction. } \\
\text { Reduction in the amounts of } \\
\text { toxic heavy metals. }\end{array}$ & [97] \\
\hline Shell & Crawfish & Pigments & $\begin{array}{l}\text { Temperature: } 50-70{ }^{\circ} \mathrm{C} \\
\text { Pressure: } 13.8-31.0 \mathrm{MPa} \\
\mathrm{CO}_{2} \text { flow: } 1.0-1.5 \mathrm{~L} / \mathrm{min} \\
\text { Co-solvent: } 10 \% \text { ethanol }\end{array}$ & $\begin{array}{l}\text { Increase extraction yield: } \\
\text { Astaxanthin }(197.6 \mathrm{mg} / \mathrm{kg})\end{array}$ & [98] \\
\hline
\end{tabular}

Recently, PUFA-rich lipids, in particular DHA and EPA, have been recovered with high yields (94\% relative to the yield of Soxhlet extraction) from Rock lobster livers by SFE extraction [97]. Besides the use of this technique to obtain essential fatty acids for human consumption from this discard material, it also allowed us to reduce the presence of heavy metals in a product usually characterized by high contamination levels of arsenic and cadmium. This is due to the ability of SFE to carry out selective extraction of low-polar lipid compounds, retaining polar impurities such as some organic derivatives with heavy metals [85].

Another important compound that can be obtained from shellfish by-products is astaxanthin. As commented previously, astaxanthin is a pigment present in marine foods [99], such as fish (salmon and trout) and shellfish (shrimp and lobster). SFE is a selective and precise method that allows the extraction of astaxanthin from crustacean samples [95,98,100,101], achieving yields of total carotenoid extraction up to $98 \%$, vs. $84 \%$ obtained with conventional extraction methods [100]. Depending on the extraction conditions, it is possible to achieve astaxanthin yields of about $40 \%$ [101]. Redspotted shrimp (Farfantepenaeus paulensis) heads, shells and tails are another source of astaxanthin, but the yields obtained by SFE in the published study by Sánchez-Camargo et al. (2011) were low [95]. The use of ethanol as co-solvent in different ratios improved the extraction of astaxanthin, as it allowed one to extract more than non-polar compounds [102], increasing the recoveries significantly $(65.2 \%$ vs. $36 \%)$ [103]. Crawfish shell is also a source of astaxanthin. The application of similar SFE conditions $\left(50{ }^{\circ} \mathrm{C}, 22.4 \mathrm{MPa}, 1.0-1.5 \mathrm{~L} / \mathrm{min}\right.$ of $\mathrm{CO}_{2}$ flow rate, $10 \%$ of ethanol) to previously reviewed studies resulted in a significant increase of the extraction yield $(197.6 \mathrm{mg} / \mathrm{kg})[98]$.

\section{Conclusions}

There is a great increase in interest for the extraction of bioactive compounds from fish and shellfish by-products due to their nutritional value and potential health benefits. The valorization strategy of seafood by-products based on the development of novel products can lead to the more environmentally sustainable use of marine resources and higher economic benefits for the sector. It is thus critical to define appropriate extraction technologies that allow minimizing processing, maximizing quality and yield and ensuring product safety (non-toxic organic solvents) meeting thus the objectives for sustainable development in achieving food safety and food security for the increasing global human population. UAE and SFE are two emerging technologies that allow enhancing the extraction of thermolabile bioactive compounds, maintaining their quality and oxidative stability. Combining UAE and SFE with other extraction methods (ISP, SWH or enzymatic methods) can further 
increase extraction yields and reduce the presence of undesirable compounds (heavy metals). Finally, the use of UAE and SFE as a pretreatment to other methods offers the possibility of extracting even more valuable compounds from fish by-product matrices.

Author Contributions: Conceptualization, F.A.K., M.P., and R.D.; writing-original draft preparation, F.A.K., and M.P.; writing-review and editing, M.P., J.M.L., E.F., P.G., K.K., H.B. and F.J.B. All authors have read and approved the final manuscript.

Funding: This research received no external funding.

Acknowledgments: Authors would like to acknowledge the EU Commission for the funds provided by the BBI-JU through the H2020 Project AQUABIOPRO-FIT “Aquaculture and agriculture biomass side stream proteins and bioactives for feed, fitness and health promoting nutritional supplements" (Grant Agreement no. 790956). Thanks to GAIN (Axencia Galega de Innovación) for supporting this review (grant numberIN607A2019/01).

Conflicts of Interest: The authors declare no conflict of interest.

\section{References}

1. Organización de las Naciones Unidas para la Agricultura y la Alimentación Focus: Desperdicio en la Pesca Artisanal. Available online: http://www.fao.org/focus/s/fisheries/proc.htm (accessed on 29 July 2019).

2. Tørris, C.; Småstuen, M.C.; Molin, M. Nutrients in fish and possible associations with cardiovascular disease risk factors in metabolic syndrome. Nutrients 2018, 10, 952. [CrossRef] [PubMed]

3. Kundam, D.N.; Acham, I.O.; Girgih, A.T. Bioactive compounds in fish and their health benefits. Asian Food Sci. J. 2018, 4, 1-14. [CrossRef]

4. FAO. The State of World Fisheries and Aquaculture 2018-Meeting the Sustainable Development Goals; FAO: Rome, Italy, 2018; ISBN 978-92-5-130562-1.

5. Rustad, T.; Storrø, I.; Slizyte, R. Possibilities for the utilisation of marine by-products. Int. J. Food Sci. Technol. 2011, 46, 2001-2014. [CrossRef]

6. Falch, E.; Rustad, T.; Jonsdottir, R.; Shaw, N.B.; Dumay, J.; Berge, J.P.; Arason, S.; Kerry, J.P.; Sandbakk, M.; Aursand, M. Geographical and seasonal differences in lipid composition and relative weight of by-products from gadiform species. J. Food Compos. Anal. 2006, 19, 727-736. [CrossRef]

7. Vázquez, J.; Meduíña, A.; Durán, A.; Nogueira, M.; Fernández-Compás, A.; Pérez-Martín, R.; Rodríguez-Amado, I. Production of valuable compounds and bioactive metabolites from by-products of fish discards using chemical processing, enzymatic hydrolysis, and bacterial fermentation. Mar. Drugs 2019, 17, 139. [CrossRef]

8. Villamil, O.; Váquiro, H.; Solanilla, J.F. Fish viscera protein hydrolysates: Production, potential applications and functional and bioactive properties. Food Chem. 2017, 224, 160-171. [CrossRef]

9. Arvanitoyannis, I.S.; Kassaveti, A. Fish industry waste: Treatments, environmental impacts, current and potential uses. Int. J. Food Sci. Technol. 2008, 43, 726-745. [CrossRef]

10. Chalamaiah, M.; Dinesh kumar, B.; Hemalatha, R.; Jyothirmayi, T. Fish protein hydrolysates: Proximate composition, amino acid composition, antioxidant activities and applications: A review. Food Chem. 2012, 135, 3020-3038. [CrossRef]

11. Olsen, R.L.; Toppe, J.; Karunasagar, I. Challenges and realistic opportunities in the use of by-products from processing of fish and shellfish. Trends Food Sci. Technol. 2014, 36, 144-151. [CrossRef]

12. Harnedy, P.A.; FitzGerald, R.J. Bioactive peptides from marine processing waste and shellfish: A review. J. Funct. Foods 2012, 4, 6-24. [CrossRef]

13. Kim, S.-K.; Mendis, E. Bioactive compounds from marine processing byproducts-A review. Food Res. Int. 2006, 39, 383-393. [CrossRef]

14. Schmidsdorff, W. Fish meal and fish oil-not only by-products. In Fish and Fishery Products, Composition, Nutritive Properties and Stability; Ruiter, A., Ed.; CAB International: Wallingford, UK, 1995; pp. 347-376.

15. Breivik, H. Long-Chain Omega-3 Specialty Oils; The Oily Press: Cambridge, UK, 2007.

16. Singh, A.; Ahmad, S.; Ahmad, A. Green extraction methods and environmental applications of carotenoids-a review. RSC Adv. 2015, 5, 62358-62393. [CrossRef]

17. Ameer, K.; Shahbaz, H.M.; Kwon, J.-H. Green extraction methods for polyphenols from plant matrices and their byproducts: A review. Compr. Rev. Food Sci. Food Saf. 2017, 16, 295-315. [CrossRef] 
18. Poojary, M.M.; Barba, F.J.; Aliakbarian, B.; Donsì, F.; Pataro, G.; Dias, D.A.; Juliano, P. Innovative alternative technologies to extract carotenoids from microalgae and seaweeds. Mar. Drugs 2016, 14, 214. [CrossRef]

19. Barba, F.J.; Roselló-Soto, E.; Brnčić, M.; Lorenzo, J.M. Green Extraction and Valorization of By-Products from Food Processing from Food Processing, CRC Press: Boca Raton, FL, USA, 2020; ISBN 978100054.

20. European Commission DIRECTIVE 2008/98/EC on waste and repealing certain Directives. Off. J. Eur. Union 2008, L 312, 3-30.

21. European Commission Discarding and the Landing Obligation Fisheries. Available online: https://ec.europa. eu/fisheries/cfp/fishing_rules/discards_en (accessed on 29 July 2019).

22. Kim, S.-K.; Mendis, E.; Shahidi, F. Marine fisheries by-products as potential nutraceuticals: An overview. In Marine Nutraceuticals and Functional Foods; Barrow, C.J., Shahidi, F., Eds.; CRC Press: Boca Raton, FL, USA, 2007; pp. 1-23. ISBN 9781420015812.

23. Ferraro, V.; Cruz, I.B.; Jorge, R.F.; Malcata, F.X.; Pintado, M.E.; Castro, P.M.L. Valorisation of natural extracts from marine source focused on marine by-products: A review. Food Res. Int. 2010, 43, 2221-2233. [CrossRef]

24. Shahidi, F.; Ambigaipalan, P. Novel functional food ingredients from marine sources. Curr. Opin. Food Sci. 2015, 2, 123-129. [CrossRef]

25. Teves, J.F.C.; Ragaza, J.A. The quest for indigenous aquafeed ingredients: A review. Rev. Aquac. 2016, 8, 154-171. [CrossRef]

26. Jayathilakan, K.; Sultana, K.; Radhakrishna, K.; Bawa, A.S. Utilization of byproducts and waste materials from meat, poultry and fish processing industries: A review. J. Food Sci. Technol. 2012, 49, 278-293. [CrossRef]

27. Aspevik, T.; Oterhals, Å.; Rønning, S.B.; Altintzoglou, T.; Wubshet, S.G.; Gildberg, A.; Afseth, N.K.; Whitaker, R.D.; Diana Lindberg, D. Valorization of proteins from co- and by-products from the fish and meat industry. In Chemistry and Chemical Technologies in Waste Valorization; Springer: Cham, Switzerland, 2017; pp. 123-150.

28. Kudre, T.G.; Bhaskar, N.; Sakhare, P.Z. Optimization and characterization of biodiesel production from rohu (Labeo rohita) processing waste. Renew. Energy 2017, 113, 1408-1418. [CrossRef]

29. Zhang, R.; El-Mashad, H.M. Bio-diesel and bio-gas production from seafood processing by-products. In Maximising the Value of Marine By-Products; Woodhead Publishing: Cambridge, England, 2007; pp. 460-485. ISBN 9781845690137.

30. Blanco, M.; Sotelo, C.G.; Chapela, M.J.; Pérez-Martín, R.I. Towards sustainable and efficient use of fishery resources: Present and future trends. Trends Food Sci. Technol. 2007, 18, 29-36. [CrossRef]

31. Ordóñez-Del Pazo, T.; Antelo, L.T.; Franco-Uría, A.; Pérez-Martín, R.I.; Sotelo, C.G.; Alonso, A.A. Fish discards management in selected Spanish and Portuguese métiers: Identification and potential valorisation. Trends Food Sci. Technol. 2014, 36, 29-43. [CrossRef]

32. Vázquez, J.A.; Durán, A.I.; Menduíña, A.; Nogueira, M.; Fraguas, J.; Mirón, J.; Valcárcel, J. Tailor-made process to recover high added value compounds from fishery by-products. In Green Extraction and Valorization of By-Products from Food Processing; Barba, F.J., Roselló-Soto, E., Brncic, M., Lorenzo, J.M., Eds.; CRC Press: Boca Raton, FL, USA, 2019; pp. 91-140. ISBN 9781138544048.

33. Silva, T.; Moreira-Silva, J.; Marques, A.; Domingues, A.; Bayon, Y.; Reis, R.; Silva, T.H.; Moreira-Silva, J.; Marques, A.L.P.; Domingues, A.; et al. Marine origin collagens and its potential applications. Mar. Drugs 2014, 12, 5881-5901. [CrossRef]

34. Hamed, I.; Özogul, F.; Regenstein, J.M. Industrial applications of crustacean by-products (chitin, chitosan, and chitooligosaccharides): A review. Trends Food Sci. Technol. 2016, 48, 40-50. [CrossRef]

35. Alves, M.H.M.E.; Nascimento, G.A.; Cabrera, M.P.; Silvério, S.I.; Da, C.; Nobre, C.; Teixeira, J.A.; de Carvalho, L.B. Trypsin purification using magnetic particles of azocasein-iron composite. Food Chem. 2017, 226, 75-78. [CrossRef]

36. Lassoued, I.; Mora, L.; Nasri, R.; Jridi, M.; Toldrá, F.; Aristoy, M.-C.; Barkia, A.; Nasri, M. Characterization and comparative assessment of antioxidant and ACE inhibitory activities of thornback ray gelatin hydrolysates. J. Funct. Foods 2015, 13, 225-238. [CrossRef]

37. Maccari, F.; Galeotti, F.; Volpi, N. Isolation and structural characterization of chondroitin sulfate from bony fishes. Carbohydr. Polym. 2015, 129, 143-147. [CrossRef]

38. Cheng, C.Y.; Duan, W.W.; Duan, Z.H.; Hai, Y.; Lei, X.G.; Chang, H. Extraction of chondroitin sulfate from tilapia byproducts with ultrasonic-microwave synergistic. Adv. Mater. Res. 2013, 726-731, 4381-4385. [CrossRef] 
39. Ciriminna, R.; Meneguzzo, F.; Delisi, R.; Pagliaro, M. Enhancing and improving the extraction of omega-3 from fish oil. Sustain. Chem. Pharm. 2017, 5, 54-59. [CrossRef]

40. Ferraro, V.; Carvalho, A.P.; Piccirillo, C.; Santos, M.M.; Castro, P.M.; Pintado, M.E. Extraction of high added value biological compounds from sardine, sardine-type fish and mackerel canning residues-A review. Mater. Sci. Eng. C 2013, 33, 3111-3120. [CrossRef]

41. Toppe, J.; Albrektsen, S.; Hope, B.; Aksnes, A. Chemical composition, mineral content and amino acid and lipid profiles in bones from various fish species. Comp. Biochem. Physiol. Part B Biochem. Mol. Biol. 2007, 146, 395-401. [CrossRef] [PubMed]

42. Zamora-Sillero, J.; Gharsallaoui, A.; Prentice, C. Peptides from fish by-product protein hydrolysates and its functional properties: An overview. Mar. Biotechnol. 2018, 20, 118-130. [CrossRef] [PubMed]

43. Ishak, N.H.; Sarbon, N.M. A review of protein hydrolysates and bioactive peptides deriving from wastes generated by fish processing. Food Bioprocess Technol. 2018, 11, 2-16. [CrossRef]

44. Létisse, M.; Comeau, L. Enrichment of eicosapentaenoic acid and docosahexaenoic acid from sardine by-products by supercritical fluid fractionation. J. Sep. Sci. 2008, 31, 1374-1380. [CrossRef]

45. Atef, M.; Mahdi Ojagh, S. Health benefits and food applications of bioactive compounds from fish byproducts: A review. J. Funct. Foods 2017, 35, 673-681. [CrossRef]

46. Halim, N.R.A.; Yusof, H.M.; Sarbon, N.M. Functional and bioactive properties of fish protein hydolysates and peptides: A comprehensive review. Trends Food Sci. Technol. 2016, 51, 24-33. [CrossRef]

47. He, S.; Franco, C.; Zhang, W. Functions, applications and production of protein hydrolysates from fish processing co-products (FPCP). Food Res. Int. 2013, 50, 289-297. [CrossRef]

48. Hansen, J.S.; Rosnes, J.T.; Skuland, A.V.; Solstad, R.G.; Kousoulaki, K. Technical and sensory properties of salmon burgers added soluble peptide-rich fish proteins. In Proceedings of the WEFTA, Tórshavn, Faroe Islands, 15-17 October 2019.

49. Galanakis, C.M. Nutraceutical and Functional Food Components: Effects of Innovative Processing Techniques; Academic Press: Cambridge, MA, USA, 2017. ISBN 9780128096505.

50. Ivanovs, K.; Blumberga, D. Extraction of fish oil using green extraction methods: A short review. Energy Procedia 2017, 128, 477-483. [CrossRef]

51. Zhao, Y.-M.; de Alba, M.; Sun, D.-W.; Tiwari, B. Principles and recent applications of novel non-thermal processing technologies for the fish industry-A review. Crit. Rev. Food Sci. Nutr. 2019, 59, 728-742. [CrossRef] [PubMed]

52. Gómez, B.; Munekata, P.E.S.; Gavahian, M.; Barba, F.J.; Martí-Quijal, F.J.; Bolumar, T.; Campagnol, P.C.B.; Tomasevic, I.; Lorenzo, J.M. Application of pulsed electric fields in meat and fish processing industries: An overview. Food Res. Int. 2019, 123, 95-105. [CrossRef] [PubMed]

53. Gallo, M.; Ferrara, L.; Naviglio, D. Application of ultrasound in food science and technology: A perspective. Foods 2018, 7, 164. [CrossRef] [PubMed]

54. Arvanitoyannis, I.S.; Kotsanopoulos, K.V.; Savva, A.G. Use of ultrasounds in the food industry-Methods and effects on quality, safety, and organoleptic characteristics of foods: A review. Crit. Rev. Food Sci. Nutr. 2017, 57, 109-128. [CrossRef] [PubMed]

55. Arzeni, C.; Martínez, K.; Zema, P.; Arias, A.; Pérez, O.E.; Pilosof, A.M.R. Comparative study of high intensity ultrasound effects on food proteins functionality. J. Food Eng. 2012, 108, 463-472. [CrossRef]

56. Chemat, F.; Khan, M.K. Applications of ultrasound in food technology: Processing, preservation and extraction. Ultrason. Sonochem. 2011, 18, 813-835. [CrossRef]

57. Soria, A.C.; Villamiel, M. Effect of ultrasound on the technological properties and bioactivity of food: A review. Trends Food Sci. Technol. 2010, 21, 323-331. [CrossRef]

58. Awad, T.S.; Moharram, H.A.; Shaltout, O.E.; Asker, D.; Youssef, M.M. Applications of ultrasound in analysis, processing and quality control of food: A review. Food Res. Int. 2012, 48, 410-427. [CrossRef]

59. Huang, T.; Tu, Z.C.; Shangguan, X.; Wang, H.; Zhang, L.; Sha, X. Rheological and structural properties of fish scales gelatin: Effects of conventional and ultrasound-assisted extraction. Int. J. Food Prop. 2017, 20, 1210-1220. [CrossRef]

60. Kim, H.K.; Kim, Y.H.; Park, H.J.; Lee, N.H. Application of ultrasonic treatment to extraction of collagen from the skins of sea bass Lateolabrax japonicus. Fish. Sci. 2013, 79, 849-856. [CrossRef]

61. Schmidt, M.M.; Dornelles, R.C.P.; Mello, R.O.; Kubota, E.H.; Mazutti, M.A.; Kempka, A.P.; Demiate, I.M. Collagen extraction process. Int. Food Res. J. 2016, 23, 913-922. 
62. Karim, A.A.; Bhat, R. Fish gelatin: Properties, challenges, and prospects as an alternative to mammalian gelatins. Food Hydrocoll. 2009, 23, 563-576. [CrossRef]

63. Tu, Z.-C.; Huang, T.; Wang, H.; Sha, X.-M.; Shi, Y.; Huang, X.-Q.; Man, Z.-Z.; Li, D.-J. Physico-chemical properties of gelatin from bighead carp (Hypophthalmichthys nobilis) scales by ultrasound-assisted extraction. J. Food Sci. Technol. 2015, 52, 2166-2174. [CrossRef] [PubMed]

64. Bruno, S.F.; Kudre, T.G.; Bhaskar, N. Impact of pretreatment-assisted enzymatic extraction on recovery, physicochemical and rheological properties of oil from Labeo rohita head. J. Food Process Eng. 2019, 42. [CrossRef]

65. Kjartansson, G.T.; Zivanovic, S.; Kristbergsson, K.; Weiss, J. Sonication-assisted extraction of chitin from shells of fresh water prawns (Macrobrachium rosenbergii). J. Agric. Food Chem. 2006, 54, 3317-3323. [CrossRef] [PubMed]

66. Álvarez, C.; Lélu, P.; Lynch, S.A.; Tiwari, B.K. Optimised protein recovery from mackerel whole fish by using sequential acid/alkaline isoelectric solubilization precipitation (ISP) extraction assisted by ultrasound. LWT Food Sci. Technol. 2018, 88, 210-216. [CrossRef]

67. Rinaudo, M. Chitin and chitosan: Properties and applications. Prog. Polym. Sci. 2006, 31, 603-632. [CrossRef]

68. Hayes, M.; Tiwari, B.K. Bioactive carbohydrates and peptides in foods: An overview of sources, downstream processing steps and associated bioactivities. Int. J. Mol. Sci. 2015, 16, 22485-22508. [CrossRef]

69. Nguyen, T.T.; Barber, A.R.; Corbin, K.; Zhang, W. Lobster processing by-products as valuable bioresource of marine functional ingredients, nutraceuticals, and pharmaceuticals. Bioresour. Bioprocess. 2017, 4, 27. [CrossRef]

70. Bruno, S.F.; Ekorong, F.J.A.A.; Karkal, S.S.; Cathrine, M.S.B.; Kudre, T.G. Green and innovative techniques for recovery of valuable compounds from seafood by-products and discards: A review. Trends Food Sci. Technol. 2019, 85, 10-22. [CrossRef]

71. Sahena, F.; Zaidul, I.S.M.; Jinap, S.; Saari, N.; Jahurul, H.A.; Abbas, K.A.; Norulaini, N.A. PUFAs in fish: Extraction, fractionation, importance in health. Compr. Rev. Food Sci. Food Saf. 2009, 8, 59-74. [CrossRef]

72. Herrero, M.; Mendiola, J.A.; Cifuentes, A.; Ibáñez, E. Supercritical fluid extraction: Recent advances and applications. J. Chromatogr. A 2010, 1217, 2495-2511. [CrossRef] [PubMed]

73. Plaza, M.; Rodríguez-Meizoso, I. Advanced extraction processes to obtain bioactives from marine foods. In Bioactive Compounds from Marine Foods; John Wiley \& Sons Ltd: Chichester, UK, 2013; pp. 343-371.

74. Nautiyal Omprakash, H. Food processing by supercritical carbon dioxide-Review Omprakash. EC Chem. 2016, 2, 111-135.

75. Reverchon, E.; De Marco, I. Supercritical fluid extraction and fractionation of natural matter. J. Supercrit. Fluids 2006, 38, 146-166. [CrossRef]

76. Tacon, A.G.J.; Metian, M. Global overview on the use of fish meal and fish oil in industrially compounded aquafeeds: Trends and future prospects. Aquaculture 2008, 285, 146-158. [CrossRef]

77. Bucio, S.L.; Sanz, M.T.; Beltrán, S.; Melgosa, R.; Solaesa, Á.G.; Ruiz, M.O. Study of the influence of process parameters on liquid and supercritical $\mathrm{CO}_{2}$ extraction of oil from rendered materials: Fish meal and oil characterization. J. Supercrit. Fluids 2016, 107, 270-277. [CrossRef]

78. Taati, M.M.; Shabanpour, B.; Ojagh, M. Extraction of oil from tuna by-product by supercritical fluid extraction (SFE) and comparison with wet reduction method. AACL Bioflux 2017, 10, 1546-1553.

79. Kuvendziev, S.; Lisichkov, K.; Zeković, Z.; Marinkovski, M.; Musliu, Z.H. Supercritical fluid extraction of fish oil from common carp (Cyprinus carpio L.) tissues. J. Supercrit. Fluids 2018, 133, 528-534. [CrossRef]

80. Ferdosh, S.; Sarker, M.Z.I.; Rahman, N.N.N.A.; Akanda, M.J.H.; Ghafoor, K.; Kadir, M.O.A. Simultaneous extraction and fractionation of fish oil from tuna by-product using supercritical carbon dioxide $\left(\mathrm{SC}-\mathrm{CO}_{2}\right)$. J. Aquat. Food Prod. Technol. 2016, 25, 230-239. [CrossRef]

81. Sahena, F.; Zaidul, I.S.M.; Norulaini, N.N.A.; Jinap, S.; Jahurul, M.H.A.; Omar, M.A.K. Storage stability and quality of polyunsaturated fatty acid rich oil fraction from Longtail tuna (Thunnus tonggol) head using supercritical extraction. CYTA J. Food 2014, 12, 183-188. [CrossRef]

82. Fang, Y.; Liu, S.; Hu, W.; Zhang, J.; Ding, Y.; Liu, J. Extraction of oil from high-moisture tuna livers by subcritical dimethyl ether: A comparison with different extraction methods. Eur. J. Lipid Sci. Technol. 2019, 121, 1800087. [CrossRef] 
83. Haque, A.S.M.; Asaduzzaman, A.K.M.; Chun, B.S. Fatty acid composition and stability of extracted mackerel muscle oil and oil-polyethylene glycol particles formed by gas saturated solution process. Fish. Aquat. Sci. 2014, 17, 67-73. [CrossRef]

84. Haq, M.; Ahmed, R.; Cho, Y.J.; Chun, B.S. Quality properties and bio-potentiality of edible oils from atlantic salmon by-products extracted by supercritial carbon dioxide and conventional methods. Waste Biomass Valoriz. 2017, 8, 1953-1967. [CrossRef]

85. Rubio-Rodríguez, N.; de Diego, S.M.; Beltrán, S.; Jaime, I.; Sanz, M.T.; Rovira, J. Supercritical fluid extraction of fish oil from fish by-products: A comparison with other extraction methods. J. Food Eng. 2012, 109, 238-248. [CrossRef]

86. Sahena, F.; Zaidul, I.S.M.; Jinap, S.; Jahurul, M.H.A.; Khatib, A.; Norulaini, N.A.N. Extraction of fish oil from the skin of Indian mackerel using supercritical fluids. J. Food Eng. 2010, 99, 63-69. [CrossRef]

87. Uddin, M.S.; Ahn, H.-M.; Kishimura, H.; Chun, B.-S. Comparative study of digestive enzymes of squid (Todarodes pacificus) viscera after supercritical carbon dioxide and organic solvent extraction. Biotechnol. Bioprocess Eng. 2009, 14, 338-344. [CrossRef]

88. Uddin, M.S.; Ahn, H.-M.; Kishimura, H.; Chun, B.-S. Production of valued materials from squid viscera by subcritical water hydrolysis. J. Environ. Biol. 2010, 31, 675-679.

89. Uddin, M.S.; Kishimura, H.; Chun, B.-S. Isolation and characterization of lecithin from squid (Todarodes pacificus) viscera deoiled by supercritical carbon dioxide extraction. J. Food Sci. 2011, 76, C350-C354. [CrossRef]

90. Lisichkov, K.; Kuvendziev, S.; Zeković, Z.; Marinkovski, M. Influence of operating parameters on the supercritical carbon dioxide extraction of bioactive components from common carp (Cyprinus carpio L.) viscera. Sep. Purif. Technol. 2014, 138, 191-197. [CrossRef]

91. Rubio-Rodríguez, N.; de Diego, S.M.; Beltrán, S.; Jaime, I.; Sanz, M.T.; Rovira, J. Supercritical fluid extraction of the omega-3 rich oil contained in hake (Merluccius capensis-Merluccius paradoxus) by-products: Study of the influence of process parameters on the extraction yield and oil quality. J. Supercrit. Fluids 2008, 47, 215-226. [CrossRef]

92. Khaw, K.; Parat, M.; Shaw, P.N.; Falconer, J.R. Solvent supercritical fluid technologies to extract bioactive compounds from natural sources: A Review. Molecules 2017, 22, 1186. [CrossRef] [PubMed]

93. Cheng, H.; Zhu, X.; Zhu, C.; Qian, J.; Zhu, N.; Zhao, L.; Chen, J. Hydrolysis technology of biomass waste to produce amino acids in sub-critical water. Bioresour. Technol. 2008, 99, 3337-3341. [CrossRef] [PubMed]

94. Amiguet, V.T.; Kramp, K.L.; Mao, J.; McRae, C.; Goulah, A.; Kimpe, L.E.; Blais, J.M.; Arnason, J.T. Supercritical carbon dioxide extraction of polyunsaturated fatty acids from Northern shrimp (Pandalus borealis Kreyer) processing by-products. Food Chem. 2012, 130, 853-858. [CrossRef]

95. Sánchez-Camargo, A.P.; Almeida Meireles, M.Â.; Lopes, B.L.F.; Cabral, F.A. Proximate composition and extraction of carotenoids and lipids from Brazilian redspotted shrimp waste (Farfantepenaeus paulensis). J. Food Eng. 2011, 102, 87-93. [CrossRef]

96. Sánchez-Camargo, A.P.; Martinez-Correa, H.A.; Paviani, L.C.; Cabral, F.A. Supercritical $\mathrm{CO}_{2}$ extraction of lipids and astaxanthin from Brazilian redspotted shrimp waste (Farfantepenaeus paulensis). J. Supercrit. Fluids 2011, 56, 164-173. [CrossRef]

97. Nguyen, T.T.; Zhang, W.; Barber, A.R.; Su, P.; He, S. Significant enrichment of polyunsaturated fatty acids (PUFAs) in the lipids extracted by supercritical $\mathrm{CO}_{2}$ from the livers of australian rock lobsters (Jasus edwardsii). J. Agric. Food Chem. 2015, 63, 4621-4628. [CrossRef]

98. Charest, D.J.; Balaban, M.O.; Marshall, M.R.; Cornell, J.A. Astaxanthin extraction from crawfish shells by supercritical $\mathrm{CO}_{2}$ with ethanol as cosolvent. J. Aquat. Food Prod. Technol. 2001, 10, 81-96. [CrossRef]

99. Shahidi, F.; Brown, J.A. Carotenoid pigments in seafoods and aquaculture. Crit. Rev. Food Sci. Nutr. 1998, 38, 1-67. [CrossRef]

100. López, M.; Arce, L.; Garrido, J.; Ríos, A.; Valcárcel, M. Selective extraction of astaxanthin from crustaceans by use of supercritical carbon dioxide. Talanta 2004, 64, 726-731. [CrossRef]

101. Félix-Valenzuela, L.; Higuera-Ciapara, I.; Goycoolea-Valencia, F.; Argüelles-Monal, W. Supercritical $\mathrm{CO}_{2}$ /ethanol extraction of astaxanthin from blue crab (Callinectes sapidus) shell waste. J. Food Process Eng. 2001, 24, 101-112. [CrossRef] 
102. Ali-Nehari, A.; Chun, B.-S. Characterization of purified phospholipids from krill (Euphausia superba) residues deoiled by supercritical carbon dioxide. Korean J. Chem. Eng. 2012, 29, 918-924. [CrossRef]

103. Sánchez-Camargo, A.P.; Meireles, M.Â.A.; Ferreira, A.L.K.; Saito, E.; Cabral, F.A. Extraction of $\omega-3$ fatty acids and astaxanthin from Brazilian redspotted shrimp waste using supercritical $\mathrm{CO}_{2}+$ ethanol mixtures. J. Supercrit. Fluids 2012, 61, 71-77. [CrossRef] 